No. 07-6

\title{
How Strong is the Macroeconomic Case for Downward Real Wage Rigidity?
}

\author{
Steinar Holden and Fredrik Wulfsberg
}

\begin{abstract}
:
This paper explores the existence of downward real wage rigidity (DRWR) in 19 OECD countries, over the period 1973-1999, using data for hourly nominal earnings at the industry level. Based on a nonparametric statistical method, which allows for country- and yearspecific variation in both the median and the dispersion of industry wage changes, we find evidence of some DRWR in OECD countries overall, as well as for specific geographical regions and time periods. There is some evidence that real wage cuts are less prevalent in countries with strict employment protection legislation and high union density. Generally, we find stronger evidence for downward nominal wage rigidity than for downward real wage rigidity.
\end{abstract}

JEL Classifications: J3, J5, C14, C15, E31

Steinar Holden is full professor at the University of Oslo as well a scientific advisor to the Research Department of Norges Bank. Fredrik Wulfsberg is head of research for the monetary policy group in the Research Department of Norges Bank and a visiting scholar at the Federal Reserve Bank of Boston. Their email addresses are steinar.holden@econ.uio.no and fredrik.wulfsberg@norges-bank.no.

We are grateful to Erling Barth, Claudia Buch, Jeff Fuhrer, Elizabeth Murry, Tyler Williams, and seminar participants at Norges Bank, University of Tuebingen, Norwegian School of Business and Administration, EEA2006, and SOLE 2007 for useful comments. Wulfsberg is also grateful for the hospitality of the Federal Reserve Bank of Boston. This paper has previously been circulated under the title "Are Real Wages Rigid Downwards?"

This paper, which may be revised, is available on the web site of the Federal Reserve Bank of Boston at http://www.bos.frb.org/economic/wp/index.htm.

The views expressed in this paper are solely those of the authors and are not those of the Federal Reserve System or the Federal Reserve Bank of Boston.

This version: June 27, 2007 


\section{Introduction}

The question of whether real wages display downward rigidity is important for assessing the effects of adverse shocks to the economy. In early explanations of the persistent European unemployment problem, a leading idea held that when unemployment rose due to various types of shocks, real wages remained high, preventing unemployment from declining again (see for example Grubb, Layard and Jackman, 1983 and Bruno and Sachs, 1985). More recently, real wage rigidity has become a key component of several contributions to the business cycle and monetary policy literature. Erceg, Henderson, and Levin (2000), Smets and Wouters (2003), and Danthine and Kurmann (2006) find that real wage rigidity plays an important role when calibrating dynamic stochastic general equilibrium models to data. Blanchard and Gali (2005) argue that real wage rigidity is a crucial element in understanding persistent inflation, while Hall (2005) and Shimer (2005) argue that real wage rigidity is necessary to explain the large cyclical variation in job vacancies. The effects of real wage rigidity are, however, a matter of some controversy. Mortensen and Nagyál (2006) argue that real wage rigidity is overemphasized in explaining labor market fluctuations. Consistent with Hall (2005) and Shimer (2005), Krause and Lubik (2006) find that allowing for real wage rigidity leads to more realistic labor market flows, but they also find that real wage rigidity has a weak effect on inflation dynamics.

The key role played by real wage rigidity in these studies, combined with the controversy as to the importance of the effects, increases the need for empirical evidence on the extent of wage rigidity in different countries. We focus on one specific aspect of sluggish wages, namely to what extent real wages are rigid downwards. If present, downward real wage rigidity (DRWR) is particularly relevant for how the economy functions in a downturn, as DRWR affects how adverse shocks may lead to higher unemployment rather than to lower wages. Our analysis also sheds some light on whether wage rigidity is asymmetric. Such asymmetry is important for the properties and welfare costs of business cycle fluctuations, as it would imply that even if a shock is reversed, real wages need not revert to their original level.

Several recent studies, including the International Wage Flexibility Project, have found em- 
pirical evidence for the existence of considerable DRWR in a number of OECD countries, mostly based on microeconomic data (see Barwell and Schweitzer, 2004; Bauer, Bonin and Sunde, 2004; Christofides and Li, 2005; Cornelissen and Hübler, 2005 and Dickens et al., 2005). In contrast to these studies, we explore the existence of DRWR at the industry level, based on data from 19 OECD countries for the period 1973-99, covering in total 449 country-year samples. More specifically, we investigate whether there are "too few" real wage cuts in the country-year specific distributions of industry wage changes, compared to what one would expect without the existence of DRWR.

The studies based on microeconomic data provide valuable evidence of wage rigidity for individual job stayers. However, it is not clear that DRWR for job stayers implies the same degree of rigidity at more aggregate levels. Firms may respond to individual wage rigidity by other means, such as giving smaller raises to other workers, or by changing the composition of the work force. And even if wage rigidity binds in some firms, wages may fall in other firms, shifting jobs over to them. Consistent with this hypothesis, Farès and Lemieux (2001) find that in Canada most of the real wage adjustments over the business cycle are experienced by new entrants.

If the effects of DRWR for individual job stayers is weakened by such uneven mechanisms, it is not clear what are the aggregate effects. It is even possible that the individual wage rigidity is entirely offset, in which case one would not expect DRWR to have important macroeconomic or allocative effects. Another possibility is that these mechanisms are unimportant, making wage rigidity more difficult to detect, but not removing its implications. It is difficult to distinguish between these possibilities using data for individual job stayers. In contrast, if we detect DRWR in industry-level data, we know that the rigidity prevails in spite of varying compositional effects.

An alternative approach would be to look for direct evidence of real wage rigidity on aggregate time series data, followed by studying the macroeconomic implications. In an influential study, Layard, Nickell, and Jackman (1991) find evidence of asymmetric real wage rigidity in a number of OECD countries, indicating worker resistance to allowing adverse terms-of-trade shocks to depress wages. More recently, Nickell et al. (2003) and Nunziata (2005) find evidence of real wage resistance, consistent with the notion that wage setters oppose a reduction in wages relative to 
consumer prices. In contrast to this literature, we limit our focus to a direct test of DRWR, which is rarely done in time series work. We benefit from a panel data set across countries, years, and industries, which provides more information than most studies of aggregate data. In particular, when compared to other studies of wage rigidity, the broader scope across countries and time increases our ability to explore whether wage rigidity is affected by a country's economic and institutional variables. Overall, our study should detect other aspects affecting DRWR than found in previous studies using other types of data.

The method we use builds on our previous work on downward nominal wage rigidity (Holden and Wulfsberg, 2007). Using data for real hourly earnings only, the method is a non-parametric variant of the skewness-location approach of McLaughlin (1994). In our test, we construct notional (as if no rigidity exists) country-year specific distributions of wage changes. We derive the shape of the notional distributions on the basis of country-year samples with high real and nominal wage growth, where downward rigidities are less likely to bind. Furthermore, we condition the distributions on the empirical location and dispersion of the country-year samples, to allow for the variation in productivity growth, markups, and the extent of sectoral shocks that exist in an extensive data set such as this one. Based on the country-year specific notional distributions, we can calculate the probability of a real wage cut for each country year. We then run simulations over all country-years, using the country-year specific notional probabilities, and compare the number of simulated, notional real wage cuts with the number of empirical real wage cuts. If the number of notional wage cuts is significantly larger than the empirical counterpart, we conclude that wages are rigid downwards. Robustness checks in Holden and Wulfsberg (2007) indicate that this method has very good properties for detecting the downward wage rigidity that exists in the data.

Most previous work on downward wage rigidity has focused on downward nominal wage rigidity, DNwR (see surveys in Camba-Mendez, Garcia and Palenzuela, 2003, and Holden, 2004). Downward rigidity might apply to nominal values if people care about nominal wages (as some studies indicate they do), if contracts are written using nominal terms, or if inflation serves as a 
vehicle for a coordinated reduction in real wages (as implied by Keynes' argument for the existence of downward nominal wage rigidity). Yet it is real, not nominal wages, that rational agents should care about. There are also several other reasons for why we would expect real wages to be rigid downwards, as discussed in sections 2 and 3. Thus it seems necessary to explore the existence of DRWR. Distinguishing between downward real and downward nominal wage rigidity is, among other things, crucial for assessing the interaction between inflation and wage rigidity.

The remainder of the paper is organized as follows. Section 2 discuss mechanisms which can explain DRWR and in section 3 we lay out the theoretical framework. In section 4 we present our data, and discuss our empirical approach. We give the results in section 5 and 6 , and conclusions in section 7 .

\section{Mechanisms Explaining Downward Real Wage Rigidity}

The idea that wage setting is influenced by the aspirations of the wage setters has been suggested and discussed by many economists. As mentioned in the introduction, this idea was highly influential as an early explanation of the persistent European unemployment problem (see the discussion and references in Alogoskoufis and Manning, 1988). It was argued that workers had learned to expect steady growth in real wages because of the fast economic growth in the 1950s and 1960s, and that this expectation would lead to greater wage pressure if productivity growth became less favorable. The theoretical justification for such an effect, however, was disputed (see for example the sharp critique by Phelps, 1992).

Various types of efficiency wage or bargaining models provide numerous explanations as to why, in a situation of high unemployment, real wages do not fall in order to clear the labour market. However, by themselves these theories do not assign a role for path dependence when wages are rigid compared to past or aspired levels. Downward wage rigidity, in the sense that the past wage level has an independent effect on the current wage level, in addition to the effect of other factors, requires a role for effects that are usually not included in standard economic models.

Recent studies have put forward two main explanations for DRWR. First, within the rationality 
assumptions usually adopted in economics, Ellingsen and Holden (1998) and Postlewaite, Samuelson, and Silverman (2004) show that real wage resistance may follow if consumption patterns are costly to change. For example, if a high wage has induced a person to buy an expensive house, and it is costly to switch to a cheaper one, the consequence could be that the person might be willing to take higher risk of being laid off when pushing to preserve the high wage. Likewise,a utilitarian union might prefer a fight to uphold the real wage if an adverse shock takes place, so as to preserve the consumption patterns for the majority of its members, even if this action implies that a minority of the workers may be laid off and may have to sell their houses.

A second behavioral justification for DRWR argues that agents specifically dislike negative changes in their income more than they value additional gains. There is now considerable experimental evidence documenting that many individuals do display such behavior. A number of studies have documented the existence of loss aversion, meaning that people are more averse to losses relative to their reference level than they are attracted to the same-sized gains (Kahneman and Tversky, 1979). Loss aversion gives rise to the endowment effect, which holds that once a person possesses a good, he or she values it more. Falk and Fehr (2005) show in experiments that employers abstain from accepting bids from workers that involve undercutting prevailing wages, out of fear that lower wages may have an adverse effect on work efforts. The same finding is documented in recent studies of managers and firm owners, (see for example Bewley, 1999 and Agell and Lundborg, 2003). Thus, there is a serious possibility that real wages can display downward rigidity.

\section{DRWR and the Distribution of Wage Changes}

As a theoretical framework for the empirical exercise, we formulate a simple model of firm-level wage bargaining, where loss aversion with respect to past real wages is the source of DRWR. The formulation draws upon Bhaskar (1990), Driscoll and Holden (2004), and, in particular, McDonald and Sibly (2005). We have chosen a union-firm framework, partly because in most OECD countries, the majority of the workforce is covered by collective bargaining agreements. However, the model's 
key features could also be derived in other settings, such as in an efficiency wage framework, as long as one maintains the crucial assumption that workers experience a utility loss if their wages fall.

Let the profits of the firm be a decreasing function of the real wage $w{ }^{1}$

$$
\pi=w^{1-\eta}, \quad \text { where } \eta>2
$$

and $\eta$ is the elasticity of product demand. A worker in a job with a given number of hours is assumed to have an indirect utility function which depends on the current and past real wages, $w$ and $w_{-1}$,

$$
V=w^{1+D \mu} w_{-1}^{-D \mu}, \quad \text { where } \mu \geq 0
$$

and where $D$ is a dummy variable which is equal to unity if real wages fall, meaning that $w<w_{-1}$, and is zero otherwise. As long as real wages do not fall, utility is simply linear in current real wages. However, we allow for the possibility that workers compare their current wage with their past wage (if $\mu>0$ ), incurring an additional utility loss if the real wage falls. In this case, utility is still continuous in current and past real wages, and strictly increasing in current real wages. Yet there is a kink in the utility function at the point where the wage is equal to its past value, implying that utility is non-differentiable from the left (when $w<w_{-1}$ ) at the point $w=w_{-1}$. The model assumes that all workers are organized in a union, and the union is assumed to represent the interests of the median worker, who, under a seniority layoff rule, is certain to keep his or her job. Thus (2) can also be thought of as the union's payoff function.

We model the wage setting by use of the (symmetric) Nash bargaining solution, where the bargaining outcome is the wage that maximizes the product of the firm's and the union's gain from reaching an agreement, that is the payoffs as compared to the disagreement points, $\pi_{0}$ for

\footnotetext{
${ }^{1}$ This profit function follows from a model of monopolistic competition, in which firms set the output price facing a downward sloping demand curve, $\eta$ is the elasticity of demand, labor is the only production factor, and there are constant returns to scale. Irrelevant constants are omitted.
} 
the firm (for simplicity set to zero), and $V_{0}$ for the union: ${ }^{2}$

$$
w=\operatorname{argmax}\left[w^{1-\eta}\left(w^{1+D \mu} w_{-1}^{-D \mu}-V_{0}\right)\right] \quad \text { s.t. } \pi \geq 0 \text { and } V \geq V_{0}
$$

If the bargainers fail to reach an agreement, the union's disagreement point, $V_{0}>0$, will depend on variables that influence the workers' payoff, such as the rate of unemployment, unemployment benefits, and outside wages. As shown in appendix A, the solution to (3) is given as follows:

$$
w= \begin{cases}\left(\frac{\eta-1}{\eta-\mu-2} w_{-1}^{\mu} V_{0}\right)^{\frac{1}{1+\mu}} & \text { if } V_{0}<V_{0}^{L}, \\ w_{-1} & \text { if } V_{0} \in\left[V_{0}^{L}, V_{0}^{H}\right], \\ \frac{\eta-1}{\eta-2} V_{0} & \text { if } V_{0}>V_{0}^{H},\end{cases}
$$

where the two critical values for $V_{0}$ are defined as

$$
\begin{gathered}
V_{0}^{L}=\frac{\eta-\mu-2}{\eta-1} w_{-1}, \text { and } \\
V_{0}^{H}=\frac{\eta-2}{\eta-1} w_{-1}>V_{0}^{L} .
\end{gathered}
$$

As in a standard wage bargaining model without a kink in the utility function (for example Layard, Nickell, and Jackman, 1991), the wage is a markup over the workers' disagreement point, and the markup depends on the elasticity of product demand $\eta$. However, due to the non-differentiability of the utility function, the negotiating outcome also depends on the past wage. If workers are in a weak bargaining position due to a low disagreement point, $V_{0}<V_{0}^{L}$, their real wage will be cut. Yet their resistance towards a cut in the real wage will imply that they get a higher real wage than they otherwise would have received. In Figure 1, this is illustrated by the solid line - the bargaining outcome - coinciding with the upper dashed curve. If workers are in a strong bargaining position, $V_{0}>V_{0}^{H}$, they will get a real wage increase. Yet since they do not have to

\footnotetext{
${ }^{2}$ We omit that if the bargaining outcome is affected by past wages, rational agents should take the effect on future bargaining outcomes into consideration during the negotiations. The risk that DRWR may bind in the future, pushing wages up, will lead wage setters to choose a lower wage today (see Holden, 1997 and Elsby, 2006). However, this consideration will not prevent the effect of DRWR that binds, which is what we look for in the empirical analysis.
} 


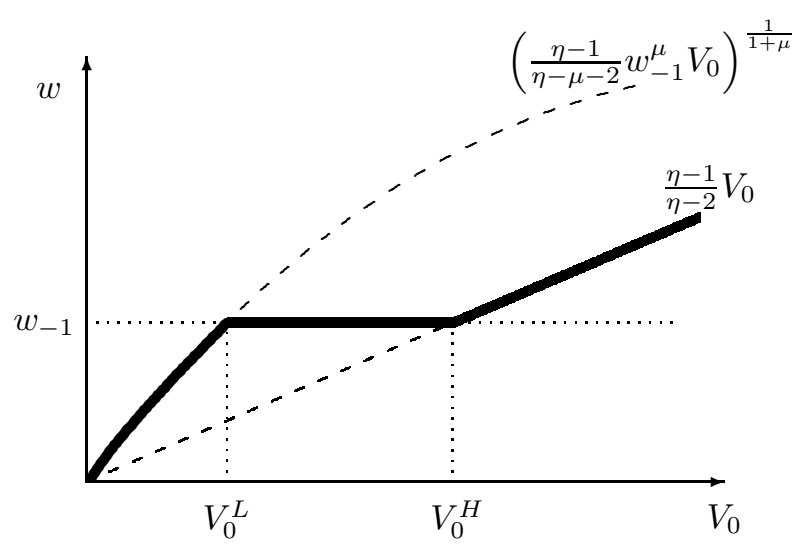

Figure 1: The upper dashed line indicates the wage outcome conditional on a wage cut, while the lower dashed line is conditional on no wage cut. The solid line indicates the bargaining outcome, coinciding with the upper dashed line below $V_{0}^{L}$, and with the lower dashed line above $V_{0}^{H}$. The real wage is cut if $V_{0}<V_{0}^{L}$, yet the workers' resistance of the wage cut implies that they obtain the real wage associated with the upper dashed line.

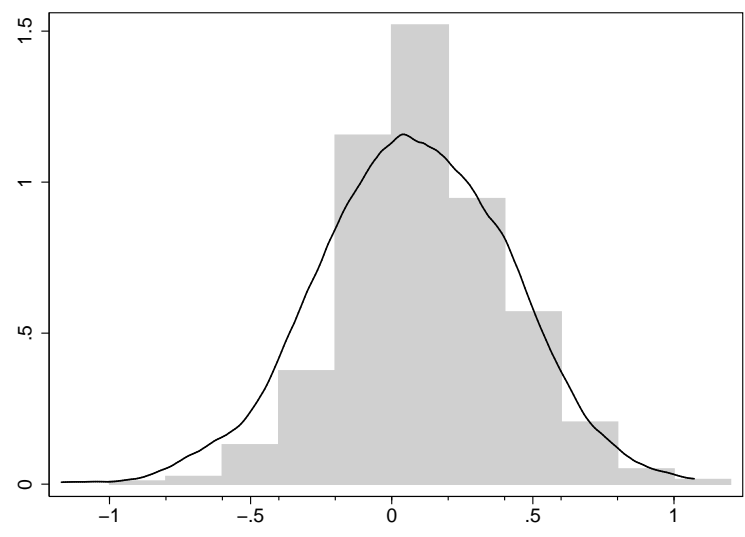

Figure 2: A notional distribution of real wage changes (solid line) and a histogram of a distribution of real wage changes. $\left(\eta=3, \mu=0.1, V_{0} \sim\right.$ $N(-0.62,0.35), V_{0}^{L} \approx V^{P 30}, V_{0}^{H} \approx V_{0}^{P 40}$, and $\varepsilon \sim$ $N(0,0.01)$.)

resist a wage cut, they fight less for higher wages. Thus, the outcome indicated by the solid line in Figure 1 coincides with the lower dashed line. For medium levels of the disagreement point, the real wage remains constant, as the workers are not able to push wages up, nor is the firm able to push wages down.

The histogram in Figure 2 provides a graphical illustration of the wage-change distribution from the bargaining model (4). There are many identical firms, and the workers' disagreement point is treated as a random variable with a normal distribution. We also add an error term to the wage change to capture, among other things, the effect of inflation surprises - in view of the fact that wages usually are set on annual basis, and in nominal terms, with none or partial price indexation. The solid line in Figure 2 represents the wage-change distribution in the absence of rigidities $(\mu=0)$, which in the literature is referred to as the notional wage-change distribution (Akerlof, Dickens and Perry, 1996). We observe that there is a deficit of negative real wage changes in the histogram compared to the the notional distribution. The model's parameters are 
chosen so that 40 percent of the notional real wage changes are negative (see the figure caption for parameter values). Of these potential wage cuts, 15 percent are prevented by DRWR (because $\mu=0.1$ ), implying that the rigid wage-change distribution is skewed to the right.

Note that the model implies that the deficit of wage cuts depends on the size of the cut. In fact, there are more small wage cuts between -2 and 0 percent compared to the notional distribution, while 31 percent of notional wage changes below -2 percent are prevented by DRWR. The intuition for this effect is that while DRWR prevents some small wage cuts, DRWR also means that larger wage cuts are reduced to a smaller size. In our case the latter effect dominates the former, so that the net effect is a preponderance of small cuts relative to the notional distribution. (Clearly, this feature is also due to the error term, in which half of the observations with constant real wages become wage cuts.)

The theoretical model allows us to show how DRWR relates to the literature, referred to in the introduction, concerned with the weak response of real wages to unemployment. As pointed out by Alogoskoufis and Manning (1988), one can decompose the weak response into two conceptually different mechanisms: (i) unemployment has a small direct effect on real wages, and (ii) real wages have a sluggish adjustment. In our model, the latter effect is represented by a positive partial effect of past wages, that is $\mu>0$, and it is this effect we look for in the empirical exercises below. The first effect corresponds to a small partial derivative $\partial V_{0} / \partial U$ (where $U$ is unemployment), which would lead to reduced dispersion of the distribution of wage changes. This reduced dispersion would, however, not depend on the location of the distribution, meaning whether the real wage change is positive or negative.

\subsection{Effects of Aggregation, Compositional Changes, Spillover, and Expecta- tions}

In contrast to microeconomic studies on DRWR, which typically explore the change in hourly earnings of individual job stayers, the observational unit in our data is the change in the average hourly earnings for all manual workers in a given industry. There are two key differences between 
these approaches. First, our data entails averaging over all job stayers. Second, the average industry-level wages are affected by compositional changes of workers, as the wages of new workers differ from the wages of those who leave (see formal framework in appendix B).

The average wage increase for job stayers may mask wage cuts for some workers if other job stayers receive wage increases. This aggregation will tend to reduce the incidence of real wage cuts (given that the economy-wide wage change is positive), as the average wage change has a lower variance than individual wage changes.

As for compositional changes of workers, one may expect to find both systematic and random effects. There will be a systematic negative effect as older workers who leave the labour force have, on average, higher wages than younger newcomers to the labor market. This difference will increase the number of wage cuts observed in the data. Second, one may expect cyclical effects, as the share of low-skilled workers may increase in expansions (see Solon, Barsky and Parker, 1994). This latter compositional effect is likely to dampen fluctuations in wage growth, thus reducing the number of wage cuts. For instance, in recessions, when wage growth for job stayers is likely to be low, the increased share of high-skilled workers will imply a positive compositional effect. Overall, the effect of systematic compositional changes on the number of wage cuts is ambiguous. In contrast, the random element arising from unsystematic turnover may be considered as "noise" relative to individual wage rigidity. The noise effect implies that we will find less DRWR.

In addition to the aggregation and composition effects discussed above, we must take into account that DRWR for some workers will have implications for the wages of other workers in the same industry. One such effect would be if firms respond to downward rigidity at the individual level, perhaps by giving lower wage increases to other workers, or by changing the composition of the workforce. Workers whose wages are cut may quit, and the replacements may accept the lower wage. Furthermore, binding wage rigidity in some firms may raise unemployment in the industry, pushing down wages in other firms. If these other firms respond by increasing their hiring, it may offset the overall effects on industry employment. Thus, it seems important to explore the extent of DRWR at the industry level. 
In practice, wage setting is based on the expected rate of inflation. This implies that wage setters whose expected rate of inflation is below the actual rate of inflation may end up with a negative real wage change, even if binding DRWR pushes the expected real wage change up to zero. However, in our main approach, we try to detect the amount of downward wage rigidity that is present in actual real wages, irrespective of whether the flexibility is caused by flexible wage setting, compositional effects, or expectational errors. Thus, we deflate wage changes by the actual rate of inflation. Yet as a sensitivity test, we also try our approach using estimates of expected inflation.

Most of the previous literature on DRWR focusses on the existence of DRWR at zero, which implies that real wage cuts are prevented. However, it is not obvious that we should focus exclusively on zero. First, our stylized theoretical model shows that DRWR may reduce the real wage cut but not prevent it entirely, implying that the deficit of wage cuts compared to the notional distribution is greater for wage change rates below zero. Second, the compositional and other effects mentioned above may lead to downward rigidities at different levels than zero, even if the rigidity is at zero for individual employees. Third, if DRWR binds for wage setters whose expected rate of inflation is, say, one percent below the actual rate of inflation, then their actual real wage change is pushed down to minus one percent. Thus, in addition to real wage rigidity at zero (preventing real wage cuts), we consider rigidity at -2 and -5 percent (that is $\Delta w<-2$ and $\Delta w<-5)$. For comparison, we also consider nominal wage rigidity, that is if $\Delta w+\pi<0$, where $\pi$ is the rate of inflation.

Overall, our study complements previous work based on microeconomic data. Aggregation and compositional effects will weaken the ability to detect DRWR, most likely implying that we will detect less DRWR than found in microeconomic studies. Yet if we do find DRWR in our data, this would imply that at the individual level DRWR is not offset by wage flexibility for other workers in the same industry, making it more likely that the DRWR also affects aggregate variables. 


\section{Empirical Approach}

We use an unbalanced panel of industry-level data for the annual percentage growth of gross hourly earnings for manual workers from the manufacturing, mining and quarrying, construction and electricity, gas and water supply sectors of 19 OECD countries in the period 1973-1999. The countries included in the sample are Austria, Belgium, Canada, Denmark, Finland, France, Germany, Greece, Ireland, Italy, Luxembourg, the Netherlands, New Zealand, Norway, Portugal, Spain, Sweden, the United Kingdom, and the United States. The main data sources for wages are harmonized hourly earnings from Eurostat and manufacturing wages from the International Labour Organization, measured for a reference period (typically October or the last quarter of the year. $)^{3}$ To measure real wages we deflate the nominal wage with the average consumer price index over the year. Thus, we look for rigidity in consumer real wages, not producer real wages, as our theoretical motivation for DRWR comes from workers' preferences, which are related to consumer real wages. One observation of real wage growth is denoted $\Delta w_{j i t}$, where $j$ is the industry index, $i$ is the country index and $t$ is the year index. In total, there are 9509 observations distributed across 449 country-year samples, with an average of 21 industries per country-year.

In our data we observe no less than $Y=3092$ events of real wage cuts, which is 32.5 percent of all observations. Only 72 (16 percent) of the 449 country-year samples have no real wage cuts. Table $\mathrm{C} 1$ in the data appendix reports the distribution of real wage cuts and observations across countries and years. More details on the data are provided in appendix C.

To explore the existence of DRWR, we extend the method that we use to detect downward nominal wage rigidity in Holden and Wulfsberg (2007). To understand the method's basic idea, consider the distribution of the real wage changes for 16 Austrian industries in 1988, depicted in Figure 3. In this histogram, there seem to be fewer negative real wage changes than in a hypothetical notional distribution, as seen in Figure 2. However, there are two problems with this kind of "eyeball econometrics". First, we do not know what the notional wage-change distribution

\footnotetext{
${ }^{3}$ The data for Austria, Canada, Finland, New Zealand, Sweden, and the United States are from the International Labour Organization, while the data for Norway is from Statistics Norway. The data for the other countries are from Eurostat.
} 


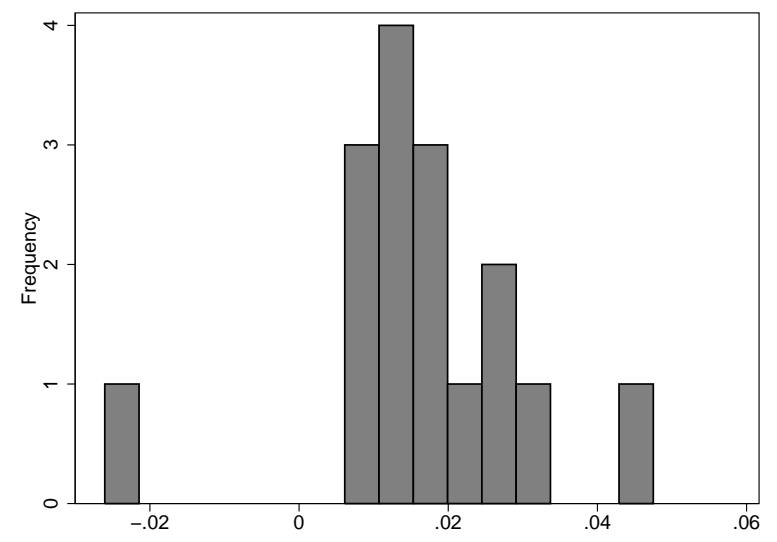

Figure 3: Histogram of real wage growth in Austria, 1988.

looks like, as it is not observed. Second, even if we did know the notional distribution, we still would need a statistical method to infer whether a deficit of real wage cuts constitutes a significant discrepancy between the empirical and the notional distribution.

We approach these problems by constructing the notional wage-change distributions on the basis of country-year samples with high median nominal and real wage growth (the details are outlined below), on the assumption that these samples are much less affected by any downward rigidities. Comparing country-year empirical histograms of wage growth reveals, not surprisingly, that the location of the distribution varies considerably between countries and over time, presumably depending on variables like inflation and aggregate productivity growth. The dispersion of the distribution also varies considerably across countries and time, depending on the size and dispersion of industry-specific shocks in that country-year. Thus, it seems imperative to allow for cross-country variation in the location and dispersion of the notional distributions. To do this, we construct country-year specific notional distributions by adjusting the underlying distribution with the empirical country-year specific median and inter-percentile range.

Earlier studies like Kahn (1997) and Lebow, Saks, and Wilson (2003) have used more restrictive assumptions than ours. Most importantly, these studies make the assumption that the notional wage change distribution does not vary with inflation; an assumption that does not hold in 
our data (see also discussion in Nickell and Quintini (2003) and Holden and Wulfsberg (2007).) The method used in Nickell and Quintini (2003) allows for variation in dispersion across years, but it involves the approximation that the density function is linear over the range relevant for wage rigidity - again an assumption that does not hold in our case. Recently, Christofides and Nearchou (2006) have suggested an extension of the Kahn method with much less restrictive assumptions. However, this method seems difficult to adapt to tests of wage rigidity at several different thresholds, not only at zero, which is important in our setting. Overall, the alternative methods used in the literature seems less suitable for our study's data and purpose.

\subsection{Constructing the notional distribution}

Specifically, we construct an underlying distribution based on a subset $H$ of the sample, with $S^{H}=1,331$ observations from the 66 country-year samples, where both the median nominal and the median real wage growth are among their respective upper quartiles, implying that the median nominal wage growth is above 11.8 percent, and the median real wage growth is above 2.8 percent. Constructing the underlying distribution on this selection of 66 country-year samples is clearly somewhat arbitrary, but other subsamples of country-years with high inflation yield similar results (see also extensive robustness checks below). To mitigate any effect of DRWR and outliers, we follow Nickell and Quintini (2003) and measure the location by the median, and the dispersion by the range between the 35 th and the 75 th percentiles, rather than the mean and the standard deviation. The underlying distribution of wage changes is then constructed by using the 66 samples with high median nominal and real wage growth, by subtracting the corresponding country-year specific median $\left(\mu_{i t}\right)$, and dividing by the inter-percentile range $\left(P 75_{i t}-P 35_{i t}\right)$ :

$$
\Delta w_{s}^{u} \equiv\left(\frac{\Delta w_{j i t}-\mu_{i t}}{P 75_{i t}-P 35_{i t}}\right), \quad \forall j, i, t \in H \text { and } s=1, \ldots, S^{H}
$$

where subscript $s$ runs over all $j, i$, and $t$ in the 66 country-year samples. The left panel of Figure 4 compares the underlying notional distribution of wage changes (illustrated by the histogram 

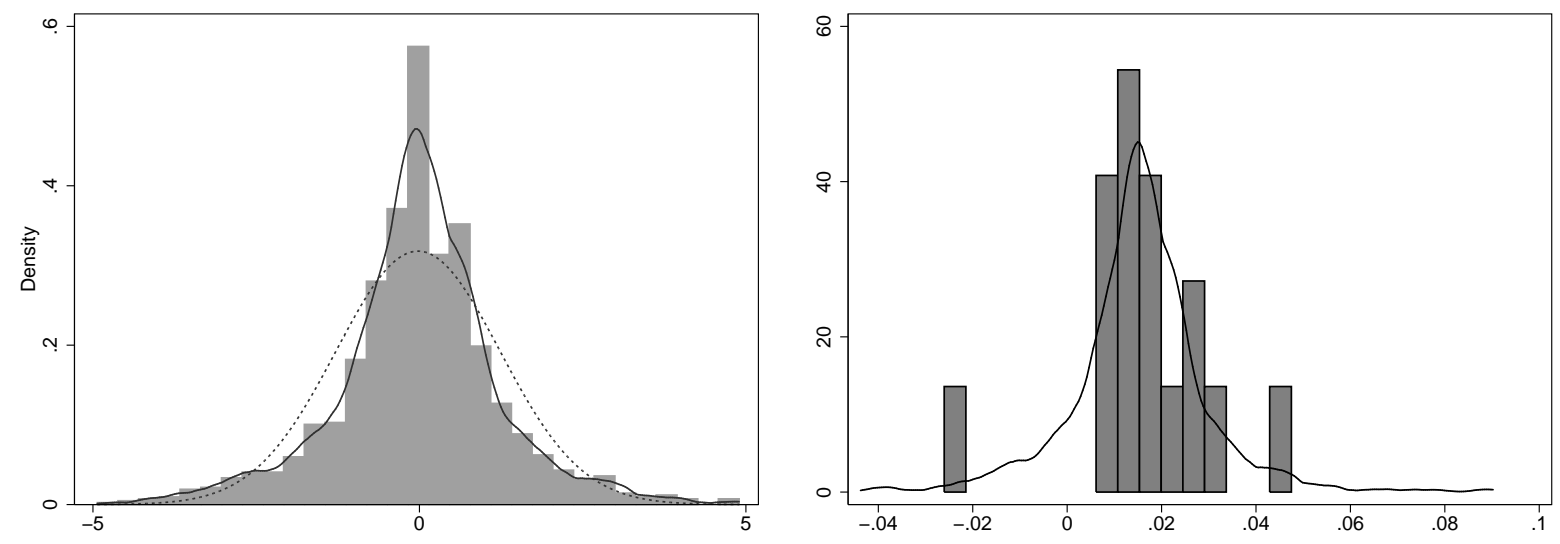

Figure 4: Left: Histogram and kernel density (solid line) of the normalized underlying distribution of wage changes compared to the normal density (dotted line). Fourteen extreme observations are omitted. Right: Histogram of observed real wage changes and the notional real wage-change distribution (solid line) in Austria, 1988.

and the kernel density in solid line) with the standard normal distribution (dotted line). Notice that the underlying distribution is asymmetric, as it is slightly skewed right. ${ }^{4}$

Then, for each of the 449 country-years in the overall sample, we construct notional countryyear specific distributions of wage changes by adjusting the underlying wage change distribution for the country-specific observed median and inter-percentile range

$$
\Delta \widetilde{w}_{s}^{i t} \equiv \Delta w_{s}^{u}\left(P 75_{i t}-P 35_{i t}\right)+\mu_{i t}, \quad \forall i, t, \text { and } s=1, \ldots, S^{H}
$$

Thus, we have then constructed 449 notional country-year distributions, each consisting of $S^{H}=$ 1,331 wage change "observations". In the right panel of Figure 4, we have plotted the notional distribution for Austria in 1988, together with the empirical histogram. By construction, the notional country-year distributions have the same country-year median and inter-percentile range as their empirical counterparts, whereas the shape is common, given by the shape of the underlying distribution, for all notional country-year samples.

To explore the validity of assuming a common shape for all the notional distributions, we have

\footnotetext{
${ }^{4}$ The coefficient of skewness is 0.26 .
} 
undertaken Kolmogorov-Smirnov tests of equality between the common underlying distribution against one alternative where the underlying distribution is constructed separately for each country (19 tests), and one alternative where the underlying distribution is constructed separately for each of the four time periods (27 tests). The assumption of a common underlying distribution passes easily in all 46 tests with the lowest p-value of 0.211 . However, we also try a large number of other alternatives to explore the sensitivity of the assumptions, see the discussion in appendix E.

Given the notional country-year specific distributions, we can explore the extent of DRWR at different thresholds by comparing the lower tails of the notional and the empirical distributions. The point estimate of the extent of DRWR follows directly from comparing the incidence of wage cuts in the empirical and the notional distributions at zero, -2 , and -5 percent. In order to investigate DRWR at zero percent, we calculate the empirical incidence for each country-year sample $i t$ rate as

$$
q_{i t}=\frac{\# \Delta w_{j i t}<0}{S_{i t}}, \quad \forall j
$$

where $\# \Delta w_{j i t}<0$ is the number of real wage cuts, and $S_{i t}$ is the number of observations in country-year it. The notional incidence rate is calculated as

$$
\tilde{q}_{i t}=\frac{\# \Delta \widetilde{w}_{s}^{i t}<0}{S^{H}}, \quad s=1, \ldots, 1,331
$$

For country-years where there is at least one notional real wage cut, implying that $\tilde{q}_{i t}>0$, we can calculate an often used measure of downward wage rigidity, which is the fraction of real wage cuts prevented (FWCP) defined as

$$
\mathrm{FWCP}_{i t}=1-q_{i t} / \tilde{q}_{i t} .
$$

If, for example, the incidence of wage cuts in the empirical sample is half of that in the notional distribution, then the $\mathrm{FWCP}=0.5$, while the $\mathrm{FWCP}$ is negative if the empirical incidence rate is larger than the notional. For example, in Austria in 1988, the incidence rate of notional real wage 
cuts, $\tilde{q}_{i t}$, is 11 percent, while the empirical incidence rate, $q_{i t}$, is 6 percent (one real wage cut out of 16 observations). The difference in these two incidence rates implies that the FWCP is 0.5, providing suggestive evidence for DRWR in Austria in 1988.

There is a lot of variation in the incidence rates (and thus the FWCPS) across the country-year samples. In order to look for interesting patterns in these estimates across countries, we will calculate aggregate incidence rates and the FWCP for countries and periods, as well as for the overall sample (that is for all country-years). We aggregate the country-year estimates by pooling the empirical observations in the relevant sample (for example all country-years), implying that the country-year notional incidence rates are weighted according to the number of observations within the country-year. For the overall sample, the FWCP at zero percent is FWCP $=1-q / \tilde{q}=$ $1-0.325 / 0.337=0.037$. Thus, only about 4 out of 100 notional real wage cuts in the overall sample do not result in an observed wage cut due to DRWR. To investigate DRWR at -2 and -5 percent, we compute the incidence rates and FWCP accordingly. For the whole sample, the fraction of notional real wage changes below the -2 percent level that are prevented by DRWR is 0.113, while at -5 percent the FWCP is 0.184 - both are considerably higher than the FWCP at zero percent.

The finding of higher FWCP for negative rates of change than at zero is consistent with the theoretical model given in section 2; DRWR pushes up real wages even when the real wage change is negative. Interestingly, a calibrated version of the theoretical model provides a remarkably close approximation to the overall empirical results. Choosing two parameter values, $\eta=3$ and $\mu=0.033$, and drawing $V_{0}$ from the normalized underlying distribution as given by (6) (instead of using a normal distribution), we obtain FWCPs of $0.037,0.126$, and 0.162 at $0,-2$, and -5 percent. This close fit strengthens the theoretical model's interpretation that the higher FWCP for negative rates of change, -2 and -5 , is caused by DRWR pushing up real wages even when the real wage change is negative.

To test whether our estimates of the FWCP are statistically significant, we exploit the idea that the incidence rate in the notional wage change distribution can be viewed as the probability of a 
wage cut occurring if there were no DRWR. In other words, under the null hypothesis of no DRWR the number of wage cuts in country-year it with, say, 20 industries, is given by 20 independent draws from the binomial distribution with probability $\tilde{q}_{i t}$. For samples covering more than one country-year, the number of wage cuts under the null hypothesis of no DRWR, is given by the combination of several binomial distributions, with probabilities given by respective incidence rates, $\tilde{q}_{i t}$. Calculating the p-values for the number of wage cuts in the empirical samples by use of the appropriate formulaes is, however, computationally extremely demanding. Instead we compute the p-values on the basis of simulations, which is much simpler, and yet highly accurate.

Specifically, our simulation method is as follows. For each country-year $i t$, we draw $S_{i t}$ times (that is the number of industries in country-year it) from a binomial distribution with probability $\tilde{q}_{i t}$. We then add up all the simulated real wage cuts for the relevant country-years (for example for all country-years, $\widehat{Y}$ ), and compare these with the total number of wage cuts in the corresponding empirical distribution ( $\operatorname{such}$ as $Y=3,211$ ). We then repeat this procedure 5,000 times, and count the number of times where we simulate more notional wage cuts than we observe in the overall sample, denoted $\#(\widehat{Y}>Y)$. The null hypothesis is rejected with a significance level of 5 percent if $1-\#(\widehat{Y}>Y) / 5000 \leq 0.05$. We can also use the simulation results to obtain confidence intervals for our estimate of DRWR.

Note that if DRWR binds in some of the country-year samples that are used in constructing the underlying wage change distribution, the underlying wage change distribution will be compressed. Likewise, if DRWR affects our measure of the dispersion in certain country-year samples, the associated notional country-year specific distribution will also be compressed. Thus, in these cases the notional probabilities will be biased downwards, reducing the number of simulated wage cuts. This downward bias will reduce the power of our test. However, if there is no DRWR, there will be no downward bias, so it will not affect the significance level of our test. 


\section{Results}

Table 1 displays the main results. For the overall sample, we note that at zero percent (that is for constant real wages), the FWCP of 3.7 percent is highly significant. Distinguishing between time periods, the DRWR appears stronger in the 1970s and the late 1990s, with FWCP of 6-7 percent, than in the 1980s and the early 1990s.

Table 1 also reports the FWCP across geographical regions: Anglo (Canada, Ireland, New Zealand, the United Kingdom, and the United States), Core (Austria, Belgium, France, Germany, Luxembourg, and the Netherlands), Nordic (Denmark, Finland, Norway, and Sweden), and South (Italy, Greece, Portugal, and Spain). The regional classification is largely based on geography and language, but typically, countries in the same region are fairly similar when it comes to labor market institutions. Generally, there is a tendency to have high rates of unionization and fairly strict employment protection legislation (EPL) in the Nordic countries, moderate unionization and stricter EPL in the South, moderate unionization and moderate EPL in the Core, and lower unionization and weaker EPL in the Anglo countries. While the point estimates indicate some DRWR for all regions, this estimate is only significant for the Anglo and Core regions.

The subsequent columns show that for the overall sample, wages are more rigid at lower growth rates than at zero with a FWCP of 11.3 percent at -2 , and 18.4 percent at -5 . At -2 percent growth, DRWR is significant for all time periods. The FWCP is highest in the 1970s at 16.2 percent. DRWR is highest in the Core region at 18.8 percent, and is around 11 percent in the Anglo and Nordic countries. The FWCP is significant in all regions except the South. At -5 percent growth, the estimated FWCP is above 30 percent both in the Core and in the Nordic regions, while in the South, the FWCP is only 9 percent, with a p-value of almost 6 percent.

As noted above, the larger estimated FWCP at negative growth rates rather than at a growth rate of zero is consistent with the theoretical model in section 2, where DRWR pushes up negative wage changes, thus reducing the number of large wage cuts, but also increasing the number of small wage cuts. However, more prevalent DRWR at -2 and -5 percent growth rates might also be caused by rigidity at zero growth for individuals and possibly also for firms, combined with some 
Table 1: The FWCP estimated at 0,-2, -5, and $-\pi$ percent real wage growth. p-values in parentheses.

\begin{tabular}{|c|c|c|c|c|c|c|c|c|c|}
\hline \multirow[b]{3}{*}{ Category } & \multirow[b]{3}{*}{$S$} & \multicolumn{8}{|c|}{ DRWR evaluated below } \\
\hline & & \multicolumn{2}{|c|}{0 percent } & \multicolumn{2}{|c|}{-2 percent } & \multicolumn{2}{|c|}{-5 percent } & \multicolumn{2}{|c|}{$-\pi$ percent } \\
\hline & & $Y$ & FWCP & $Y$ & FWCP & $Y$ & FWCP & $Y$ & FWCP \\
\hline All observations & 9505 & 3092 & $\begin{array}{c}0.037 \\
(0.000)\end{array}$ & 1372 & $\begin{array}{c}0.113 \\
(0.000)\end{array}$ & 449 & $\begin{array}{c}0.184 \\
(0.000)\end{array}$ & 324 & $\begin{array}{c}0.260 \\
(0.000)\end{array}$ \\
\hline \multicolumn{10}{|l|}{ Periods } \\
\hline $1970-79$ & 2224 & 453 & $\begin{array}{c}0.067 \\
(0.016)\end{array}$ & 214 & $\begin{array}{l}0.162 \\
(0.000)\end{array}$ & 59 & $\begin{array}{l}0.309 \\
(0.000)\end{array}$ & 5 & $\begin{array}{l}0.612 \\
(0.011)\end{array}$ \\
\hline $1980-89$ & 3717 & 1545 & $\begin{array}{c}0.028 \\
(0.024)\end{array}$ & 755 & $\begin{array}{c}0.096 \\
(0.000)\end{array}$ & 270 & $\begin{array}{l}0.157 \\
(0.000)\end{array}$ & 74 & $\begin{array}{c}0.399 \\
(0.000)\end{array}$ \\
\hline 1990-94 & 1906 & 645 & $\begin{array}{c}0.020 \\
(0.241)\end{array}$ & 229 & $\begin{array}{c}0.109 \\
(0.017)\end{array}$ & 63 & $\begin{array}{l}0.195 \\
(0.032)\end{array}$ & 93 & $\underset{(0.002)}{0.231}$ \\
\hline 1995-99 & 1662 & 449 & $\begin{array}{c}0.058 \\
(0.041)\end{array}$ & 174 & $\begin{array}{l}0.129 \\
(0.016)\end{array}$ & 57 & $\begin{array}{l}0.146 \\
(0.105)\end{array}$ & 152 & $\begin{array}{l}0.159 \\
(0.005)\end{array}$ \\
\hline \multicolumn{10}{|l|}{ Regions } \\
\hline Anglo & 2961 & 1274 & $\begin{array}{l}0.027 \\
(0.054)\end{array}$ & 568 & $\begin{array}{c}0.113 \\
(0.000)\end{array}$ & 188 & $\begin{array}{l}0.172 \\
(0.001)\end{array}$ & 153 & $\begin{array}{c}0.199 \\
(0.001)\end{array}$ \\
\hline Core & 3110 & 788 & $\begin{array}{c}0.063 \\
(0.004)\end{array}$ & 248 & $\begin{array}{c}0.188 \\
(0.000)\end{array}$ & 48 & $\begin{array}{l}0.347 \\
(0.000)\end{array}$ & 125 & $\begin{array}{c}0.234 \\
(0.000)\end{array}$ \\
\hline Nordic & 1976 & 515 & $\begin{array}{c}0.032 \\
(0.125)\end{array}$ & 235 & $\begin{array}{l}0.117 \\
(0.002)\end{array}$ & 45 & $\begin{array}{l}0.311 \\
(0.000)\end{array}$ & 18 & $\begin{array}{c}0.498 \\
(0.000)\end{array}$ \\
\hline South & 1462 & 515 & $\begin{array}{c}0.024 \\
(0.214)\end{array}$ & 321 & $\begin{array}{c}0.043 \\
(0.147)\end{array}$ & 168 & $\begin{array}{c}0.090 \\
(0.058)\end{array}$ & 28 & $\underset{(0.001)}{0.411}$ \\
\hline
\end{tabular}

Note: $S$ is the number of observations, $Y$ is the number of observed wage cuts below the relevant limit. DRWR evaluated below $-\pi$ percent is equivalent to evaluate DNWR at 0 percent.

downward flexibility due to compositional changes between types of workers. Furthermore, more prevalent downward rigidity may reflect that some wage setters have inflation expectations that are below the actual rate of inflation.

For comparison, the last column in Table 1 reports the results for DNWR. We observe that the FWCPs are almost always higher for nominal than for real rigidity, the only exception being the Core region, where there is high real rigidity at the -5 level. The most notable difference is for the South, where the FWCP applying to nominal rigidity is more than 40 percent, and thus four times as high as the corresponding measure for real rigidity at -5 percent.

When we combine time periods and regions, we find that DRWR at -2 and -5 percent was prevalent in the Anglo, Core, and Nordic regions in the 1970s and 1980s (see Table D1 in the appendix). In contrast, in the South, there was never significant DRWR, even if the point estimates for the FWCP at -2 and -5 are small and positive in most time periods. 
Table 2: The FWCP estimated at 0,-2, -5, and $-\pi$ percent real wage growth. p-values in parentheses.

\begin{tabular}{|c|c|c|c|c|c|c|c|c|c|}
\hline \multirow[b]{3}{*}{ Category } & \multirow[b]{3}{*}{$S$} & \multicolumn{8}{|c|}{ DRWR evaluated below } \\
\hline & & \multicolumn{2}{|c|}{0 percent } & \multicolumn{2}{|c|}{-2 percent } & \multicolumn{2}{|c|}{-5 percent } & \multicolumn{2}{|c|}{$-\pi$ percent } \\
\hline & & $Y$ & FWCP & $Y$ & FWCP & $Y$ & FWCP & $Y$ & FWCP \\
\hline Austria & 408 & 60 & $\begin{array}{l}0.109 \\
(0.153)\end{array}$ & 8 & $\begin{array}{l}0.555 \\
(0.005)\end{array}$ & 0 & $\begin{array}{l}1.000 \\
(0.035)\end{array}$ & 2 & $\begin{array}{l}0.715 \\
(0.027)\end{array}$ \\
\hline Belgium & 575 & 169 & $\begin{array}{l}0.035 \\
(0.258)\end{array}$ & 69 & $\begin{array}{l}0.216 \\
(0.002)\end{array}$ & 15 & $\begin{array}{l}0.387 \\
(0.012)\end{array}$ & 31 & $\begin{array}{l}0.232 \\
(0.034)\end{array}$ \\
\hline Canada & 627 & 289 & $\begin{array}{l}0.033 \\
(0.198)\end{array}$ & 101 & $\begin{array}{l}0.099 \\
(0.120)\end{array}$ & 24 & $\begin{array}{l}0.269 \\
(0.055)\end{array}$ & 57 & $\begin{array}{l}0.078 \\
(0.260)\end{array}$ \\
\hline Denmark & 462 & 161 & $\begin{array}{c}-0.022 \\
(0.708)\end{array}$ & 76 & $\begin{array}{l}0.055 \\
(0.280)\end{array}$ & 21 & $\begin{array}{l}0.296 \\
(0.015)\end{array}$ & 8 & $\begin{array}{l}0.460 \\
(0.039)\end{array}$ \\
\hline Finland & 368 & 69 & $\begin{array}{l}0.097 \\
(0.144)\end{array}$ & 15 & $\begin{array}{l}0.488 \\
(0.001)\end{array}$ & 0 & $\begin{array}{l}1.000 \\
(0.000)\end{array}$ & 2 & $\begin{array}{l}0.664 \\
(0.063)\end{array}$ \\
\hline France & 556 & 116 & $\begin{array}{l}0.013 \\
(0.456)\end{array}$ & 39 & $\begin{array}{c}-0.049 \\
(0.674)\end{array}$ & 8 & $\begin{array}{c}-0.008 \\
(0.609)\end{array}$ & 21 & $\begin{array}{c}-0.196 \\
(0.870)\end{array}$ \\
\hline Germany & 665 & 160 & $\begin{array}{l}0.080 \\
(0.055)\end{array}$ & 24 & $\begin{array}{l}0.171 \\
(0.199)\end{array}$ & 4 & $\begin{array}{c}-0.610 \\
(0.893)\end{array}$ & 16 & $\begin{array}{l}0.062 \\
(0.453)\end{array}$ \\
\hline Greece & 469 & 195 & $\begin{array}{l}0.013 \\
(0.401)\end{array}$ & 133 & $\begin{array}{l}0.002 \\
(0.511)\end{array}$ & 71 & $\begin{array}{l}0.044 \\
(0.339)\end{array}$ & 7 & $\begin{array}{c}-0.126 \\
(0.720)\end{array}$ \\
\hline Ireland & 463 & 171 & $\begin{array}{l}0.020 \\
(0.366)\end{array}$ & 85 & $\begin{array}{l}0.148 \\
(0.035)\end{array}$ & 35 & $\begin{array}{l}0.190 \\
(0.093)\end{array}$ & 27 & $\begin{array}{l}0.326 \\
(0.012)\end{array}$ \\
\hline Italy & 312 & 76 & $\begin{array}{l}0.004 \\
(0.514)\end{array}$ & 45 & $\begin{array}{l}0.033 \\
(0.435)\end{array}$ & 22 & $\begin{array}{c}-0.014 \\
(0.587)\end{array}$ & 0 & $\begin{array}{l}1.000 \\
(0.040)\end{array}$ \\
\hline Luxembourg & 423 & 125 & $\begin{array}{l}0.130 \\
(0.015)\end{array}$ & 58 & $\begin{array}{c}0.209 \\
(0.022)\end{array}$ & 18 & $\begin{array}{l}0.376 \\
(0.016)\end{array}$ & 32 & $\begin{array}{l}0.268 \\
(0.022)\end{array}$ \\
\hline Netherlands & 483 & 158 & $\begin{array}{l}0.033 \\
(0.251)\end{array}$ & 50 & $\begin{array}{l}0.167 \\
(0.041)\end{array}$ & 3 & $\begin{array}{l}0.533 \\
(0.103)\end{array}$ & 23 & $\begin{array}{l}0.386 \\
(0.002)\end{array}$ \\
\hline New Zealand & 750 & 328 & $\begin{array}{l}0.025 \\
(0.227)\end{array}$ & 189 & $\begin{array}{l}0.106 \\
(0.010)\end{array}$ & 84 & $\begin{array}{l}0.060 \\
(0.257)\end{array}$ & 45 & $\begin{array}{l}0.218 \\
(0.034)\end{array}$ \\
\hline Norway & 674 & 133 & $\begin{array}{l}0.010 \\
(0.456)\end{array}$ & 47 & $\begin{array}{l}0.057 \\
(0.312)\end{array}$ & 2 & $\begin{array}{l}0.708 \\
(0.023)\end{array}$ & 2 & $\begin{array}{l}0.472 \\
(0.267)\end{array}$ \\
\hline Portugal & 411 & 163 & $\begin{array}{l}0.044 \\
(0.197)\end{array}$ & 106 & $\begin{array}{l}0.143 \\
(0.010)\end{array}$ & 64 & $\begin{array}{l}0.196 \\
(0.009)\end{array}$ & 3 & $\begin{array}{l}0.859 \\
(0.000)\end{array}$ \\
\hline Spain & 270 & 81 & $\begin{array}{l}0.028 \\
(0.403)\end{array}$ & 37 & $\begin{array}{c}-0.166 \\
(0.858)\end{array}$ & 11 & $\begin{array}{c}-0.214 \\
(0.799)\end{array}$ & 18 & $\begin{array}{c}-0.060 \\
(0.661)\end{array}$ \\
\hline Sweden & 472 & 152 & $\begin{array}{l}0.071 \\
(0.055)\end{array}$ & 97 & $\begin{array}{l}0.089 \\
(0.031)\end{array}$ & 22 & $\begin{array}{l}-0.099 \\
(0.755)\end{array}$ & 6 & $\begin{array}{l}0.469 \\
(0.038)\end{array}$ \\
\hline United Kingdom & 615 & 199 & $\begin{array}{l}0.033 \\
(0.235)\end{array}$ & 98 & $\begin{array}{l}0.110 \\
(0.047)\end{array}$ & 35 & $\begin{array}{l}0.274 \\
(0.003)\end{array}$ & 18 & $\begin{array}{l}0.217 \\
(0.127)\end{array}$ \\
\hline United States & 506 & 287 & $\begin{array}{l}0.023 \\
(0.226)\end{array}$ & 95 & $\begin{array}{l}0.110 \\
(0.039)\end{array}$ & 10 & $\begin{array}{l}0.265 \\
(0.158)\end{array}$ & 6 & $\begin{array}{l}0.304 \\
(0.241)\end{array}$ \\
\hline
\end{tabular}

Note: See Table 1

Table 2 shows the results for individual countries. At the -2 percent level, DRWR is significant with a FWCP of around 0.5 in Austria and Finland, and FWCP is also significant, varying between 9-21 percent in Belgium, Ireland, Luxembourg, the Netherlands, New Zealand, Portugal, Sweden, the United Kingdom, and the United States. There is no indication of DRWR at -2 percent in Canada, Denmark, France, Germany, Greece, Italy, Norway, and Spain. Figure 5 plots the country estimates of DNWR versus DRWR at -2 percent. Clearly, there is a positive correlation between 


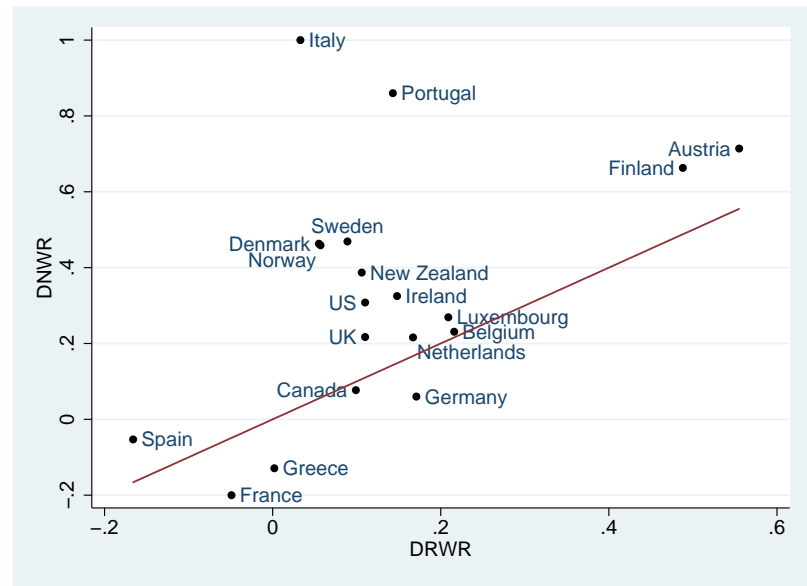

Figure 5: DNWR and DRWR at-2 percent growth by country measured by the FWCP.

the two. The outliers are Italy and Portugal, where DNWR is much stronger than DRWR.

To explore the robustness of our results, we have varied the key assumptions concerning the shape, the location, and the dispersion of the notional distributions. As to the shape of the underlying distribution, we have tried country-specific and period-specific distributions in addition to the common shape assumption. While there is considerable variation in the results from different methods, the broad picture remains the same as in our main approach. Overall, there is clear evidence of DRWR, although the extent is moderate. Significance levels and FWCPs are higher at -2 and -5 percent than at zero, and also weaker and smaller in the South than in the other regions. The details and results from the robustness tests are reported in the appendix E.

Based on data for individual job stayers, Dickens et al. (2005) find that DRWR exists at the zero growth level, with the FWCP ranging from around 5 percent in Greece and the United States to around 50 percent in Finland, France, and Sweden, with most countries in the 15-35 percent range. Compared to these results, our estimated FWCPs are much smaller, in particular at the zero growth level, but also at -2 and -5 percent growth levels. Our lower estimates, as expected, are due to the existence of compositional effects and the scope for firms to circumvent wage rigidity for individual employees. Also note that in Dickens et al. (2005) the measure of DRWR is based on individual real wages, thus DRWR will be strongly affected by the wage-change distribution within 
Table 3: The FIYA estimated at 0, -2, -5 , and $-\pi$ percent real wage growth. p-values in parentheses.

\begin{tabular}{|c|c|c|c|c|c|c|c|c|c|}
\hline \multirow[b]{3}{*}{ Category } & \multirow[b]{3}{*}{$S$} & \multicolumn{8}{|c|}{ DRWR evaluated below } \\
\hline & & \multicolumn{2}{|c|}{0 percent } & \multicolumn{2}{|c|}{-2 percent } & \multicolumn{2}{|c|}{-5 percent } & \multicolumn{2}{|c|}{$-\pi$ percent } \\
\hline & & $Y$ & FIYA & $Y$ & FIYA & $Y$ & FIYA & $Y$ & FIYA \\
\hline All observations & 9505 & 3092 & $\begin{array}{c}0.012 \\
(0.000)\end{array}$ & 1372 & $\begin{array}{c}0.018 \\
(0.000)\end{array}$ & 449 & $\begin{array}{c}0.011 \\
(0.000)\end{array}$ & 324 & $\begin{array}{c}0.012 \\
(0.000)\end{array}$ \\
\hline \multicolumn{10}{|l|}{ Periods } \\
\hline $1970-79$ & 2224 & 453 & $\begin{array}{c}0.015 \\
(0.016)\end{array}$ & 214 & $\begin{array}{c}0.019 \\
(0.000)\end{array}$ & 59 & $\underset{(0.000)}{0.012}$ & 5 & $\begin{array}{c}0.004 \\
(0.011)\end{array}$ \\
\hline $1980-89$ & 3717 & 1545 & $\begin{array}{c}0.012 \\
(0.024)\end{array}$ & 755 & $\begin{array}{c}0.021 \\
(0.000)\end{array}$ & 270 & $\begin{array}{c}0.014 \\
(0.000)\end{array}$ & 74 & $\begin{array}{l}0.013 \\
(0.000)\end{array}$ \\
\hline $1990-94$ & 1906 & 645 & $\underset{(0.241)}{0.007}$ & 229 & $\begin{array}{c}0.015 \\
(0.017)\end{array}$ & 63 & $\begin{array}{c}0.008 \\
(0.032)\end{array}$ & 93 & $\begin{array}{l}0.015 \\
(0.002)\end{array}$ \\
\hline $1995-99$ & 1662 & 449 & $\underset{(0.041)}{0.017}$ & 174 & $\begin{array}{l}0.016 \\
(0.016)\end{array}$ & 57 & $\begin{array}{l}0.006 \\
(0.105)\end{array}$ & 152 & $\begin{array}{l}0.017 \\
(0.005)\end{array}$ \\
\hline \multicolumn{10}{|l|}{ Regions } \\
\hline Anglo & 2961 & 1274 & $\underset{(0.054)}{0.012}$ & 568 & $\begin{array}{l}0.024 \\
(0.000)\end{array}$ & 188 & $\underset{(0.001)}{0.013}$ & 153 & $\underset{(0.001)}{0.013}$ \\
\hline Core & 3110 & 788 & $\begin{array}{l}0.017 \\
(0.004)\end{array}$ & 248 & $\underset{(0.000)}{0.018}$ & 48 & $\begin{array}{c}0.008 \\
(0.000)\end{array}$ & 125 & $\underset{(0.000)}{0.012}$ \\
\hline Nordic & 1976 & 515 & $\begin{array}{c}0.009 \\
(0.125)\end{array}$ & 235 & $\begin{array}{c}0.016 \\
(0.002)\end{array}$ & 45 & $\begin{array}{l}0.010 \\
(0.000)\end{array}$ & 18 & $\begin{array}{l}0.009 \\
(0.000)\end{array}$ \\
\hline South & 1462 & 515 & $\begin{array}{c}0.009 \\
(0.214)\end{array}$ & 321 & $\begin{array}{l}0.010 \\
(0.147) \\
\end{array}$ & 168 & $\begin{array}{l}0.011 \\
(0.058) \\
\end{array}$ & 28 & $\begin{array}{r}0.013 \\
(0.001)\end{array}$ \\
\hline
\end{tabular}

Note: See Table 1

firms and industries, in contrast to our measure based on average wages within industries.

Table 3 displays the fraction of industry-years, FIYA, that are affected by downward rigidity calculated as the incidence rate of notional wage changes that are below zero, -2 , and -5 percent growth, multiplied by the FWCP evaluated at each threshold. We observe that 1.8 percent of all industry-year wage changes are pushed up above the -2 percent threshold, which is higher than for any of the other thresholds. This estimate is fairly stable across time periods, and the geographic variation is also limited, ranging from 1.0 percent in the South to 2.4 percent in the Anglo countries. This underscores that DRWR is a phenomenon that affects all regions and time periods, even if the extent is moderate. 


\subsection{Errors in Expected Inflation}

To explore other possible explanations for our results, we pursue a number of alternative reasons. One possibility is that in reality DRWR applies to expected real wages, and that expectational errors regarding inflation lead to additional flexibility. To analyze this possibility, we have re-simulated the results from the main procedure using expected real wage changes, where the measure of expected inflation is derived as country-specific AR1 processes of actual inflation. The results are qualitatively similar, even though the estimated FWCPs are somewhat smaller: $0.024,0.066$ and 0.165 at levels zero, -2 , and -5 percent growth (the results are available upon request). The tendency towards weaker downward rigidity for expected, rather than for actual, real wages is the opposite of what one would expect if expectational errors regarding inflation are a key cause of real wage flexibility. Even though this finding may also reflect that our estimate for the expected inflation rate is noisy, it nevertheless suggests that expectational errors are not important for real wage flexibility.

\subsection{Symmetric or asymmetric rigidity}

We also perform the analysis with an entirely different identifying assumption that, following Card and Hyslop, assumes symmetry within each country-year notional sample. Thus, rather than using a common underlying distribution, we construct the notional distribution for each country-year sample by replacing the observations below the median by the mirror image of the observations above the median. Note that this approach makes no assumptions about the notional distributions across country-years, in contrast to the main approach, which does not assume symmetric notional distributions. As these methods are based on orthogonal assumptions, these constitute a strong test of the robustness of our results. For example, using our main approach, our finding of DRWR, might, in principle, be caused by inflation affecting the shape of the wage-change distribution apart from what is captured by location and dispersion. However, unless such an effect is asymmetric, it would not lead to finding DRWR using the symmetry method. As shown in Table F1 in the appendix, the estimated FWCPs are somewhat lower, but the results are qualitatively similar to 
Table 4: The FWCP at-2 percent by inflation intervals in percent.

\begin{tabular}{lcccccc} 
& \multicolumn{6}{c}{ Inflation interval } \\
& $\langle-\infty, 2\rangle$ & {$[2,4\rangle$} & {$[4,6\rangle$} & {$[6,8\rangle$} & {$[8,10\rangle$} & {$[10, \infty\rangle$} \\
\hline FWCP & 0.155 & 0.179 & 0.234 & 0.072 & 0.168 & 0.052 \\
No. of country-years & 69 & 107 & 67 & 50 & 47 & 109 \\
\hline
\end{tabular}

the main results. This finding strengthens our belief that our results are indeed caused by DRWR.

Note that the findings from the main approach should be interpreted as evidence of downward wage rigidity, with no bearing on whether the rigidity is symmetric or asymmetric. In contrast, by using the symmetry method, we also find evidence for the existence of asymmetric rigidity. The finding of asymmetry is of independent interest, as it suggests that even if a shock is reversed, real wages need not revert to their original level.

\subsection{Real or nominal wage rigidity?}

One possible alternative interpretation of our finding of DRWR at -2 and -5 growth levels is that the missing real wage cuts are in fact caused by downward nominal wage rigidity. We test for this possibility by exploring whether there is any relationship between the FWCP and the rate of inflation. If our findings of DRWR are caused solely by DNWR, the FWCP will be zero for high rates of inflation, and positive for low inflation rates. However, while we see from Table 4 that the FWCP at the -2 percent level is considerably higher when inflation is below 2 percent - consistent with the downward rigidity being caused by DNWR - than if inflation is above 10 percent, the FWCP is even higher for country-years where inflation rates are between 4 and 6 percent. Thus, if this deficit of real wage cuts is caused by downward nominal rigidity, there must be some downward nominal rigidity at 4 percent nominal wage growth, and not only at constant nominal wages.

The idea that downward nominal wage rigidity may in fact lead to increased nominal wages is consistent with findings by Holden (1989) and Cramton and Tracy (1992). These papers point out that in a wage bargaining situation where no strike takes place (often referred to as holdout), but when the workers simultaneously inflict a cost on the firm by working less efficiently, the firm 
can be willing to raise nominal wages to ensure reaching an agreement with the workers. Cramton and Tracy (1992) obtain empirical support for this idea using United States wage contract data, and Holden $(1989,1998)$ does the same for wage setting in the Nordic countries.

However, we also note that the FWCP is also high for inflation rates in the 8 to 10 percent interval, and even for some inflation rates above 10 percent. This FWCP suggests that part of our finding of DRWR is not caused by DNWR. Yet the overall negative relationship between the FWCPS and the rate of inflation also clearly indicates that DNWR does play a role in this connection.

\section{The Effect of Institutional and Economic Variables}

A key question is to what extent the DRWR we detect can be explained by differences in economic and institutional variables. In Holden and Wulfsberg (2007), we find that employment protection legislation, EPL, union density, and unemployment are important determinants of DNWR. Table 5 reports results from Poisson regressions for the same variables, using the number of real wage changes below -2 percent in a country-year as the dependent variable. The first two columns report results for the incidence of real wage cuts (as we condition on the number of observations in the country-year), while the last two columns report results for the FWCP (as we condition on the simulated number of real wage cuts). Inflation is found to have a positive effect on the incidence of real wage cuts. This is not surprising, given that a positive inflation shock will reduce real wages.

Consistent with our findings above, inflation also has a negative impact on the FWCP. Note that this is not caused by the same mechanism as when inflation reduces the incidence of real wage cuts. If a positive inflation shock takes place, it will move the entire real wage-change distribution, and as we condition the notional distributions on the median real wage change, a positive inflation shock will not affect the FWCP unless there is a link between the inflation shock and the distributional shape of the real wage changes. One possible cause of such a link is if the DRWR applies to expected real wages, and then is eroded if a positive inflation shock takes place. However, our findings in section 5.1 do not support this interpretation. A more plausible 
Table 5: Maximum likelihood estimates with standard errors in parenthesis from negative binomial regressions in columns one and two and from Poisson regressions in columns three and four. Significant estimates at $5 \%$ are indicated by an asterix.

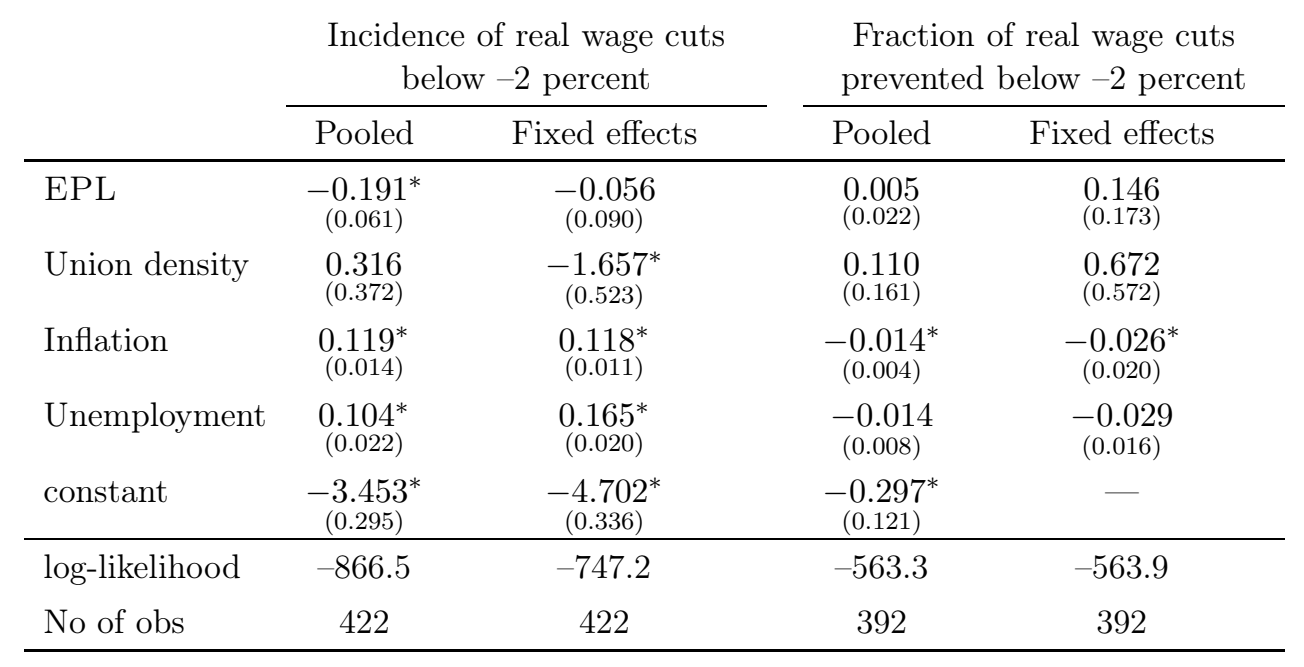

interpretation, consistent with our findings in section 5.3, is that under low inflation, DNWR also contributes to DRWR.

Unemployment has a significant positive effect on the incidence of real wage cuts, and a negative effect, although not significant, on the FWCP. EPL has the expected negative effect on the number of wage cuts in all regressions, but is only significant in one of the pooled regressions. Union density has the expected negative effect on the number of wage cuts in 3 of the 4 regressions, and is significant in one of the fixed-effect regressions. These results give some indication that DRWR is affected by labor market rigidity and unions, and that is it weakened by unemployment. As in our work on DNWR, we also used other institutional variables in this regression: bargaining coverage, temporary employment, and indexes of centralization and coordination of wage setting. However, these variables generally had even lower explanatory power than the variables that are included in Table 5. 


\section{Conclusions}

Based on data for gross hourly earnings for manual workers from the manufacturing, mining and quarrying, construction, and electricity, gas and water supply sectors of 19 OECD countries between 1973 and 1999, we explore whether real wages are rigid downwards. Distinguishing between groups of countries, we find evidence of DRWR in the core European countries, and also in some countries belonging to the Anglo group, but no evidence of DRWR in the Nordic and southern European countries. The extent of DRWR is small for the countries in which it is present. In the Core, the FWCP is 6 percent, implying that 6 percent of all notional real wage cuts are prevented by downward rigidity. In the Anglo group, the FWCP is 3 percent. However, we find stronger evidence of downward rigidity at -2 or -5 percent growth in the real wages. In the Core, 19 percent of all notional real wage cuts below -2 percent are prevented by DRWR, while in the Anglo and Nordic countries, at -2 percent growth the FWCP is around 11-12 percent. At -5 percent growth, the FWCP is above 30 percent in both the Core and the Nordic countries, about 17 percent in the Anglo group, and about 9 percent in the South (the latter with p-value of 6 percent). There is, however, considerable heterogeneity within the regions.

The higher FWCP at negative real wage changes is consistent with our theoretical model, where workers' resistance against wage cuts prevents smaller wage cuts and reduce the size of larger ones, dampening the reduction in the number of small real wage cuts. Yet the greater FWCP for negative real wage changes than for the zero growth level may also reflect compositional changes in the work force. As older high-wage workers are replaced by younger low-wage workers, average wages may exhibit a small negative change, even if individual workers avoid real wage cuts. The finding of extensive downward rigidity at -2 or -5 percent growth in real wages is important, as it underscores that the real wages need not be completely flexible downwards - even if one observes a high incidence of real wage cuts.

Comparing the downward rigidity of nominal and real wages, we find that DNWR is much more significant, and of greater magnitude, across geographic regions and time periods. The difference between DNWR and DRWR was, however, much smaller in the late 1990s than it was in earlier 
periods, reflecting a reduction in the extent of DNWR. This suggests that wages have become more flexible in nominal terms, in line with the reduction in inflation, but there has not been the same reduction in DRWR. In periods of low inflation, DNWR will also involve DRWR, and it is indeed difficult to distinguish between the two types of rigidity. However, as we also find some DRWR in high inflation periods, it seems clear that the DRWR that we find is an independent phenomenon that is not only caused by DNWR combined with a low inflation rate.

In contrast to most previous studies of DRWR, which consider the wages of job stayers, we use data for average wages at the industry level. Thus, if DRWR for job stayers is circumvented by firms that give lower wage increases to other workers, or hire new workers at lower wages, it will not be detected in our data. Nor will our data capture downward wage rigidity in some firms, if wages are flexible in other firms in the same industry, so that the industry's overall wages are flexible. However, in these cases it is questionable whether the wage rigidity at the worker- or the firm-level will have any impact at the aggregate level. In contrast, if the DRWR also prevails at the industry level, its effect on aggregate output and employment seems more likely.

Our finding of DRWR is based on a univariate framework, which only includes data for real wage growth. The univariate framework has the advantage of needing no assumptions on explanatory variables and functional forms. Thus, when we detect DRWR, we can be fairly confident that this finding is indeed a feature inherent in the data. On the other hand, by using a univariate framework, we clearly cannot directly explore how wages respond to changes in macroeconomic variables like unemployment and productivity. Doing so would be an interesting extension of our work.

Another important extension of our work would be to explore whether the wage rigidity we find has any effects on macroeconomic performance. From a theoretical perspective, this is not clear. Barro (1977) pointed out that short-run real wage rigidity need not have any effects on employment, as risk-averse parties to a long-term contract may avoid short-run fluctuations in real remuneration, without this leading to any inefficient allocative effects. However, more recently, both Shimer (2005) and Hall (2005) have argued that real wage rigidity has effects on job vacancies 
and hirings and is crucial to explaining vacancies and recruitment behavior over the business cycle. Furthermore, there is fairly strong evidence that the variation in unemployment rates across time and OECD countries is related to institutional labor market variables - like unemployment benefits, union density, and the degree of coordinated wage setting - which are likely to reflect differences in wage-setting behavior (see for example Nickell et al., 2003). Within this framework, one would expect increased wage pressure due to binding DRWR to induce higher unemployment, in line with the early explanations of the rise in European unemployment in the 1970s (see Bruno and Sachs, 1985 and Grubb, Layard and Jackman, 1983). Testing this conjecture is an important task for future research.

Overall, our finding that DRWR reduces the extent of large real wage cuts (wage changes below

-2 or -5 percent growth) across most OECD countries lends some support to the recent literature exploring the implications of real wage rigidity for business cycles and labor market fluctuations. However, one should bear in mind that we find only a limited amount of DRWR, which suggests that its possible effects on employment and output would, ultimately, be fairly small.

\section{References}

Agell, J. and P. Lundborg (2003). "Survey Evidence on Wage Rigidity and Unemployment." Scandinavian Journal of Economics 105, 15-30.

Akerlof, G., W. Dickens, and W. Perry (1996). "The Macroeconomics of Low Inflation." Brookings Papers on Economic Activity 1:1996, 1-76.

Alogoskoufis, G. and A. Manning (1988). "Unemployment Persistence." Economic Policy 3, $427-469$.

Barro, R. (1977). "Long-Term Contracting, Sticky Prices, and Monetary Policy." Journal of Monetary Economics 3(3), 305-316.

Barwell, R. and M. Schweitzer (2004). "The Incidence of Nominal and Real Wage Rigidity in Great Britain: 1978-1998." Mimeo, Bank of England.

Bauer, T., H. Bonin and U. Sunde (2004). "Real and Nominal Wage Rigidities and the Rate of Inflation: Evidence from West German Microdata." CEPR Discussion Papers 4271, C.E.P.R. Discussion Papers. 
Bewley, T. (1999). Why Wages Don't Fall During a Recession. Cambridge, MA: Harvard University Press.

Bhaskar, V. (1990). "Wage Relatives and the Natural Range of Unemployment." The Economic Journal 100(400), 60-66.

Blanchard, O., and J. Gali (2005). "Real Wage Rigidities and the New Keynesian Model." NBeR Working Papers 11806, National Bureau of Economic Research, Inc.

Blanchard, O. and J. Wolfers (2000). "The Role of Shocks and Institutions in the Rise of European Unemployment: The Aggregate Evidence." The Economic Journal 110(462), C1-C33.

Bruno, M. and J. Sachs (1985). The Economics of Worldwide Stagflation. Oxford: Basil Blackwell.

Camba-Mendez G., J.A. Garcia, and D.A. Palenzuela (2003). "Relevant Economic Issues Concerning the Optimal Rate of Inflation." Background Studies for the ECB's Evaluation of its Monetary Policy Strategy, ECB.

Christofides, L. and P. Nearchou (2006). "Real and Nominal Wage Rigidities in Collective Bargaining." Mimeo, Department of Economics, University of Cyprus

Christofides, L.N. and D. Li (2005). "Nominal and Real Wage Rigidity in a Friction Model." Mimeo, Department of Economics, University of Cyprus.

Cornelissen, T. and O. Hübler (2005). "Downward Wage Rigidity and Labour Mobility." IZA Discussion paper 1523.

Cramton, P. and J.S. Tracy (1992). "Strikes and Holdouts in Wage Bargaining: Theory and Data." American Economic Review 82, 100-121.

Danthine, J-P. and A. Kurmann (2006). "Efficiency Wages Revisited: The Internal Reference Perspective." Economics Letters 90, 278-284.

Dickens, W., L. Goette, E.L. Groshen, S. Holden, J. Messina, M.E. Schweitzer, J. Turunen, and M. Ward (2005). The interaction of labor markets and inflation: Analysis of micro data from the International Wage Flexibility project. Forthcoming in Journal of Economic Perspectives.

Driscoll, J and S. Holden (2004). "Fairness and Inflation Persistence." Journal of the European Economic Association 2, 240-251.

Ellingsen, T. and S. Holden (1998). "Sticky Consumption and Rigid Wages." In Market Behaviour and Macroeconomic Modelling, eds. Brakman, S., H. van Ees and S.K. Kuipers, 183-200. Basingstoke: MacMillan.

Elsby, M. (2006). "Evaluating the Economic Significance of Downward Nominal Wage Rigidity." NBER Working Papers 12611, National Bureau of Economic Research, Inc.

Erceg, C.J., D.W. Henderson, and A.T. Levin (2000) "Optimal Monetary Policy with Staggered Wage and Price Contracts." Journal of Monetary Economics 46, 281-313. 
Falk, A. and E. Fehr (1999). "Wage Rigidity in a Competitive Incomplete Contract Market." Journal of Political Economy 107, 106-134

Farès, J. and T. Lemieux (2001). "Downward Nominal-Wage Rigidity: A Critical Assessment and Some New Evidence for Canada" in Proceedings of the Bank of Canada Conference on Price Stability and the Long Run Target for Monetary Policy, ed. A. Crawford, 3-48.

Grubb, D., R. Layard, and R. Jackman (1983). "Wage Rigidity and Unemployment in OECD Countries." European Economic Review 21(1-2), pp. 11-39

Hall, R. (2005). "Employment Fluctuations with Equilibrium Wage Stickiness." American Economic Review 95(1), March, 50-65.

Holden, S. (1989). "Wage Drift and Bargaining. Evidence from Norway." Economica 56, 419-432.

Holden, S. (1997). "Wage Bargaining, Holdout, and Inflation." Oxford Economic Papers 49, $235-255$.

Holden, S. (1998). "Wage Drift and the Relevance of Centralised Wage Setting." Scandinavian Journal of Economics 100, 711-731.

Holden, S. (2004). "Wage Formation under Low Inflation." In Collective Bargaining and Wage Formation - Challenges for an European Labour Market, eds. H. Piekkola and K. Snellman, 39-58. Springer-Verlag.

Holden, S. and F. Wulfsberg (2007). "Downward Nominal Wage Rigidity in the OECD." Mimeo, University of Oslo and Norges Bank, http://folk.uio.no/sholden/dnwr.pdf.

ILO (1997). World Labour Report 1997-98 Industrial Relations, Democracy and Social Stability. Technical report, International Labour Organization, http://www.ilo.org/public/english/ dialogue/ifpdial/publ/wlr97/summary.htm.

Kahn, S. (1997). "Evidence of Nominal Wage Stickiness from Micro-Data." American Economic Review 87(5), 993-1008.

Kahneman, D. and A. Tversky (1979). "Prospect Theory: An Analysis of Decision under Risk." Econometrica 47, 263-291.

Knoppik, C. and T. Beissinger (2003). "How Rigid are Nominal Wages? Evidence and Implications for Germany." Scandinavian Journal of Economics 105(4), 619-641.

Krause, M., and T.A. Lubik (2006). The (Ir)relevance of Real Wage Rigidity in the New Keynesian Model with Search Frictions. Forthcoming in Journal of Macroeconomics.

Layard, R., S. Nickell, and R. Jackman (1991) Unemployment. Oxford: Oxford University Press.

Lazear, E. (1990). "Job Security Provisions and Employment." Quarterly Journal of Economics 105(3), 699-725. 
Lebow, D., R. Saks, and B. Wilson (2003). "Downward Nominal Wage Rigidity. Evidence from the Employment Cost Index." Advances in Macroeconomics 3(1), Article 2. http://www . bepress . com/bejm/advances/vol3/iss1/art2.

McDonald, I. and H. Sibly (2005). "The Diamond of Macroeconomic Equilibria and NonInflationary Expansion." Metroeconomica 56(3), 393-409.

McLaughlin, K. (1994). "Rigid Wages?" Journal of Monetary Economics 34(3), 383-414.

Mortensen, D. and E. Nagyál (2006). "More on Unemployment and Vacancy Fluctuations." Mimeo, Northwestern University.

Nickell, S. and G. Quintini (2003). "Nominal Wage Rigidity and the Rate of Inflation." The Economic Journal 113, 762-781.

Nickell, S., L. Nunciata, W. Ochel and G. Quintini (2003) "The Beveridge Curve, Unemployment, and Wages in the OECD from the 1960s to the 1990s." In Imperfect Knowledge, Information and Expectations in Modern Macroeconomics: In Honor of Edmund S Phelps, eds. P. Aghion, R. Frydman, J. Stiglitz and M. Woodford. Princeton, NJ: Princeton University Press

Nunziata, L. (2005) "Institutions and Wage Determination: A Multi-Country Approach." Oxford Bulletin of Economics and Statistics 67(4), 435-466.

OECD (2004). Employment Outook. Paris: OECD.

Phelps, E.S. (1992). "A Review of Unemployment." Journal of Economic Literature 30, 1476-1490.

Postlewaite, A., L. Samuelson, and D. Silverman (2004). "Consumption, Commitments and Preferences for Risk." NBER Working Papers 10527, National Bureau of Economic Research, Inc.

Shimer, R. (2005). "The Cyclical Behavior of Equilibrium Unemployment and Vacancies." American Economic Review 95(1), 25-49.

Smets, F. and R. Wouters (2003). "An Estimated Stochastic Dynamic General Equilibrium Model of the Euro Area Countries." Journal of the European Economic Assosiation 1(5), 1123-1175.

Solon, G., R. Barsky and J.A. Parker (1994). "Measuring the Cyclicality of Real Wages: How Important is Composition Bias?" The Quarterly Journal of Economics 109(1), 1-25. 


\section{Appendix}

\section{A The Nash Solution}

The first order condition for the Nash bargaining solution requires that the left-hand derivative (that is $w<w_{-1}$, so that $D=1$ ) of the Nash maximand satisfies

$$
\frac{d[.]^{-}}{d w}=(1-\eta) w^{-\eta}\left(w^{1+\mu} w_{-1}^{-\mu}-V_{0}\right)+w^{1-\eta}(1+\mu) w^{\mu} w_{-1}^{-\mu} \geq 0
$$

while the right-hand derivative $\left(w \geq w_{-1}\right)$ satisfies

$$
\frac{d[]^{+}}{d w}=(1-\eta) w^{-\eta}\left(w-V_{0}\right)+w^{1-\eta} \leq 0 .
$$

Furthermore, we know that either $w=w_{-1}$, or one of (A1) or (A2) hold with equality. In the case where (A1) holds with equality, we obtain

$$
w^{-}=\left(\frac{\eta-1}{\eta-\mu-2} w_{-1}^{\mu} V_{0}\right)^{\frac{1}{1+\mu}}
$$

while the case where (A2) holds with equality, we obtain

$$
w^{+}=\frac{\eta-1}{\eta-2} V_{0}
$$

The lower critical values for $V_{0}$ and $V_{0}^{L}$, are found by imposing $w=w_{-1}$ in (A3), and then solving for $V_{0}$. As $w^{-}$is strictly increasing in $V_{0}$, it follows directly that $w^{-}<w_{-1}$ for $V_{0}<V_{0}^{L}$. It is also straightforward to show that $w^{+}<w_{-1}$ for $V_{0}<V_{0}^{L}$.

Correspondingly, $V_{0}^{H}$ is found by imposing $w=w_{-1}$ in (A4), and then solving for $V_{0}$. As $w^{+}$ is strictly increasing in $V_{0}$, it follows directly that $w^{+}>w_{-1}$ for $V_{0}>V_{0}^{H}$. Furthermore, it is straightforward to show that $w^{-}>w_{-1}$ for $V_{0}>V_{0}^{H}$. Finally, it is straightforward to establish that in the interval $V_{0} \in\left[V_{0}^{L}, V_{0}^{H}\right]$, we have $w^{+}<w_{-1}<w^{-}$.

It is then clear that for $V_{0}<V_{0}^{L}$, the Nash maximand is maximized by equality in (A1), where $w=w^{-}<w_{-1}$. For $V_{0}>V_{0}^{H}$, the Nash maximand is maximized by equality in (A2) and $w=w^{+}>w_{-1}$. For $V_{0} \in\left[V_{0}^{L}, V_{0}^{H}\right]$, the Nash maximand is maximized by $w=w_{-1} \in\left[w^{+}, w^{-}\right]$, where both (A1) and (A2) hold, with strict inequalities in the interior of the interval. QED 


\section{B Decomposing the Change in Industry Wages}

Consider a simple framework where we keep hours per worker constant, and where we assume that hires and separations occur between, and not within, years (relaxing these assumptions is straightforward, but makes notation cumbersome and less transparent). Observe that the average hourly wages in an industry in year $t, \bar{w}_{t}$, can be decomposed into the average wage of all job stayers, $\bar{w}_{t}^{s}$, and that of all entrants, $\bar{w}_{t}^{e}$, that is $\bar{w}_{t}=\bar{w}_{t}^{s}\left(s / l_{t}\right)+\bar{w}_{t}^{e}\left(e / l_{t}\right)$, where $s+e=l_{t}$. (To minimize possibly confusing notation, we let $s$ refer to the number of workers who stay from year $t-1$ to year $t$, without using a time subscript, and likewise for entrants in period $\mathrm{t}, e$, and quitters in period $t-1$.) Correspondingly, the average wage in year $t-1$ can be decomposed into the average wage of workers who stay on year $t, \bar{w}_{t-1}^{s}$, and that of all who quit or are laid off, $\bar{w}_{t-1}^{q}$, that is $\bar{w}_{t-1}=\bar{w}_{t-1}^{s}\left(s / l_{t-1}\right)+\bar{w}_{t-1}^{q}\left(q / l_{t-1}\right)$, where $s+q=l_{t-1}$. Using that $\bar{w}_{t}^{s} \frac{s}{l_{t}}=\Delta \bar{w}_{t}^{s}+\bar{w}_{t-1}^{s} \frac{s}{l_{t}}-\Delta \bar{w}_{t}^{s} \frac{e}{l_{t}}$, the growth in average wages is thus

$$
\begin{aligned}
\Delta \bar{w}_{t} & =\bar{w}_{t}-\bar{w}_{t-1}=\bar{w}_{t}^{s} \frac{s}{l_{t}}+\bar{w}_{t}^{e} \frac{e}{l_{t}}-\left(\bar{w}_{t-1}^{s} \frac{s}{l_{t-1}}+\bar{w}_{t-1}^{q} \frac{q}{l_{t-1}}\right) \\
& =\Delta \bar{w}_{t}^{s}+\left[\bar{w}_{t-1}^{s} \frac{s}{l_{t}}+\left(\bar{w}_{t}^{e}-\Delta \bar{w}_{t}^{s}\right) \frac{e}{l_{t}}-\left(\bar{w}_{t-1}^{s} \frac{s}{l_{t-1}}+\bar{w}_{t-1}^{q} \frac{q}{l_{t-1}}\right)\right]
\end{aligned}
$$

where the first term is the wage increase for job stayers, while the term in the brackets is the composition effect, measured as the average wage in year $t-1$ of those who work in year $t$ relative to those who work in year $t-1$. If the employment level is constant, $l_{t}=l_{t-1}$, and $e=q$, the expression reduces down to $\Delta \bar{w}_{t}^{s}\left(s / l_{t}\right)+\left(\bar{w}_{t}^{e}-\bar{w}_{t-1}^{q}\right)\left(q / l_{t}\right)$, that is the wage growth for job stayers times the ratio of stayers to total employment, plus the difference in wages for entrants relative to quitters, times the quit rate.

\section{Data appendix}

We have obtained wage data from Eurostat for all countries except Austria, Canada, Finland, New Zealand Norway, Sweden and the United States (see below). The precise source is Table HMWHOUR in the Harmonized earnings domain under the Population and Social Conditions theme in the NEWCRONos database. Our wage variable (HMWHOUR) is labeled Gross hourly earnings of manual workers in industry. Gross earnings cover remuneration in cash paid directly and regularly by the employer at the time of each wage payment, before deducting taxes and social security contributions payable by wage earners and retained by the employer. Payments for leave, public holidays, and other paid individual absences are included in principle, in so far as the corresponding days or hours are also taken into account to calculate earnings per unit of time. The weekly work-hours of work are those in a normal working week (that is a week that does not 
include public holidays) during the reference period (October or the last quarter). These hours are calculated based on the number of hours paid, including overtime hours paid. Furthermore, we use wage data denominated in the national currency, and wages for men and women are included in the data. The data for Germany does not include the German Democratic Republic before 1990 or new Länder.

The data are recorded by classification of economic activities (NACE Rev. 1). The sections represented are: Mining and quarrying (C), Manufacturing (D), Electricity, gas, and water supply (E) and Construction (F). We use data on various levels of aggregation from the section levels (for example D Manufacturing) to group levels (for example DA 159 Manufacturing of beverages), but use the most disaggregated level available in order to maximize the number of observations. If for example, wage data are available for D, DA 158 and DA 159, we use the latter two only to avoid counting the same observations twice.

Wage data for Austria, Canada, Finland, New Zealand, Sweden and the United States are from Table 5B "Wages in manufacturing" in LABORSTA, the Labour Statistics Database, ILO. The data are recorded by ISIC, three digit level covering the same sectors as the Eurostat data. Wage data for Norway are from Table 210 National Accounts 1970-2003, Statistics Norway, recorded by NACE Rev. 1. The sections represented are the same as for the Eurostat data.

The average number of observations per country-year sample is 20.5, with a standard error of 4.7. The distribution of the number of wage cuts relative to the number of observations on years and countries is reported in Table $\mathrm{C} 1$.

We have removed ten extreme observations from the sample.

Data for inflation and unemployment are from the OECD Economic Outlook database.

The primary sources for the employment protection legislation (EPL) index, which is displayed in Holden and Wulfsberg (2007, Table A.2), are OECD (2004) for the 1980-1999 period and Lazear (1990) for the years before 1980. We follow the same procedure as Blanchard and Wolfers (2000) to construct time-varying series, which is to use the OECD summary measure in the "Late 1980s" for 1980-89 and the "Late 1990s" for 1995-99. For 1990-94 we interpolate the series. For 1973-79 the percentage change in Lazear's index is used to back-cast the OECD measure. However, we are not able to reconstruct the Blanchard and Wolfers data exactly.

Data for union density is from OECD. For Greece, date for 1978 and 1979 are interpolated, while data before 1977 is extrapolated at the 1977 level.

Bargaining coverage data are from the OECD (2004, Table 3.5), which provides data for 1980, 1990 and 2000. Data for the intervening years are calculated by interpolation, while the observations for 1980 are extrapolated backwards. Data for Greece and Ireland are only available for 1994 from the ILO (1997, Table 1.2). This observation is extrapolated for the entire period.

The incidence of temporary employment is defined as the fraction of temporary to total em- 
Table C1: The distribution of real wage cuts relative to the number of observations by countries and years

\begin{tabular}{|c|c|c|c|c|c|c|c|c|c|c|c|c|c|c|c|c|c|c|c|c|}
\hline $\begin{array}{l}1973 \\
\end{array}$ & & $0 / 20$ & & $0 / 23$ & $0 / 19$ & - & $0 / 16$ & $0 / 20$ & $1 / 12$ & - & $1 / 24$ & $0 / 14$ & $0 / 19$ & $2 / 24$ & $1 / 28$ & - & - & $1 / 21$ & $8 / 20$ & $14 / 260$ \\
\hline 1974 & $0 / 16$ & $0 / 20$ & $4 / 24$ & $2 / 23$ & $3 / 19$ & - & $0 / 16$ & $1 / 21$ & $11 / 13$ & - & $8 / 24$ & $0 / 14$ & $0 / 19$ & $2 / 25$ & $0 / 28$ & - & - & $1 / 21$ & $19 / 20$ & $51 / 303$ \\
\hline 1975 & $0 / 16$ & $1 / 20$ & $0 / 24$ & $7 / 24$ & $3 / 19$ & - & $1 / 16$ & $2 / 22$ & $0 / 13$ & - & $1 / 24$ & $1 / 15$ & $1 / 19$ & $16 / 25$ & $0 / 28$ & - & - & $5 / 21$ & $8 / 18$ & $46 / 304$ \\
\hline 1976 & $1 / 16$ & $6 / 21$ & $0 / 24$ & $0 / 24$ & $2 / 19$ & - & $7 / 16$ & $1 / 22$ & $0 / 13$ & $11 / 18$ & $4 / 24$ & $1 / 15$ & $15 / 19$ & $25 / 25$ & $0 / 28$ & - & - & $22 / 23$ & $/ 18$ & $95 / 325$ \\
\hline 1977 & $1 / 16$ & $1 / 21$ & $1 / 24$ & $1 / 24$ & $14 / 19$ & - & $12 / 16$ & $1 / 22$ & $0 / 13$ & $6 / 18$ & $2 / 24$ & $7 / 15$ & $0 / 19$ & $15 / 25$ & $0 / 28$ & - & - & $22 / 23$ & $2 / 18$ & $85 / 325$ \\
\hline 1978 & $0 / 16$ & $3 / 21$ & $23 / 24$ & $0 / 24$ & $5 / 19$ & - & $8 / 16$ & $1 / 22$ & $0 / 13$ & $1 / 18$ & $1 / 24$ & $8 / 15$ & $2 / 20$ & $2 / 25$ & $4 / 28$ & - & $4 / 26$ & $1 / 23$ & $4 / 18$ & $67 / 352$ \\
\hline 1979 & $3 / 16$ & $0 / 21$ & $16 / 24$ & $3 / 24$ & $1 / 20$ & - & $0 / 16$ & $4 / 22$ & $3 / 13$ & $1 / 20$ & $4 / 24$ & $2 / 15$ & $10 / 19$ & $7 / 25$ & $9 / 28$ & - & $12 / 28$ & $2 / 22$ & $18 / 18$ & $95 / 355$ \\
\hline 1980 & $4 / 16$ & $1 / 21$ & $9 / 24$ & $0 / 24$ & $20 / 20$ & - & $5 / 16$ & $3 / 22$ & $4 / 13$ & $15 / 19$ & $15 / 24$ & $3 / 15$ & $15 / 19$ & $23 / 25$ & $18 / 28$ & - & $14 / 28$ & $11 / 22$ & $17 / 18$ & $177 / 354$ \\
\hline 1981 & $8 / 16$ & $3 / 21$ & $14 / 23$ & $22 / 24$ & $14 / 20$ & - & $2 / 16$ & $2 / 22$ & $5 / 13$ & $14 / 19$ & $0 / 24$ & $9 / 15$ & $17 / 19$ & $4 / 25$ & $24 / 28$ & $8 / 22$ & $28 / 28$ & $12 / 22$ & $12 / 18$ & $198 / 375$ \\
\hline 1982 & $5 / 16$ & $18 / 21$ & $11 / 20$ & $19 / 24$ & $11 / 20$ & - & $4 / 16$ & $5 / 21$ & $0 / 13$ & $15 / 20$ & $10 / 24$ & $13 / 16$ & $3 / 18$ & $9 / 25$ & $13 / 28$ & $8 / 22$ & $27 / 28$ & $6 / 22$ & $4 / 18$ & $181 / 372$ \\
\hline 1983 & $3 / 16$ & $20 / 21$ & $10 / 20$ & $12 / 24$ & $18 / 20$ & - & $1 / 16$ & $0 / 21$ & $6 / 11$ & $9 / 18$ & $5 / 24$ & $9 / 16$ & $14 / 18$ & $22 / 25$ & $9 / 28$ & $17 / 22$ & $27 / 27$ & $1 / 24$ & $1 / 18$ & $184 / 369$ \\
\hline 1984 & $12 / 16$ & $21 / 21$ & $6 / 28$ & $15 / 27$ & $18 / 20$ & - & $0 / 16$ & $21 / 22$ & $1 / 17$ & $6 / 18$ & $21 / 24$ & $10 / 16$ & $15 / 16$ & $27 / 25$ & $1 / 28$ & $21 / 22$ & $1 / 27$ & $2 / 24$ & $13 / 18$ & $211 / 385$ \\
\hline 1985 & $0 / 16$ & $13 / 21$ & $17 / 28$ & $1 / 27$ & $3 / 20$ & - & $0 / 16$ & $9 / 23$ & $12 / 18$ & $5 / 20$ & $4 / 24$ & $9 / 16$ & $8 / 17$ & $28 / 25$ & $1 / 28$ & $12 / 22$ & $6 / 28$ & $22 / 24$ & $11 / 18$ & $161 / 391$ \\
\hline 1986 & $0 / 16$ & $15 / 21$ & $19 / 28$ & $0 / 27$ & $8 / 20$ & - & $0 / 16$ & $5 / 23$ & $18 / 18$ & $2 / 21$ & - & $0 / 14$ & $2 / 18$ & $3 / 25$ & $2 / 28$ & $3 / 22$ & $1 / 28$ & $2 / 24$ & $7 / 18$ & $87 / 367$ \\
\hline 1987 & $3 / 16$ & $8 / 21$ & $18 / 28$ & $0 / 27$ & $0 / 20$ & - & $0 / 16$ & $6 / 23$ & $17 / 18$ & $8 / 20$ & - & $3 / 14$ & $0 / 18$ & $23 / 25$ & $0 / 28$ & $1 / 22$ & $/ 28$ & $/ 24$ & $17 / 18$ & $104 / 366$ \\
\hline 1988 & $1 / 16$ & $6 / 21$ & $18 / 28$ & $0 / 27$ & $3 / 20$ & - & $0 / 16$ & $14 / 23$ & $1 / 18$ & $3 / 20$ & - & $3 / 14$ & $3 / 18$ & $7 / 25$ & $21 / 28$ & $8 / 21$ & $1 / 28$ & $1 / 25$ & $17 / 18$ & $107 / 367$ \\
\hline 1989 & $4 / 16$ & $3 / 22$ & $16 / 28$ & $4 / 27$ & $18 / 20$ & - & $4 / 16$ & $6 / 23$ & $1 / 17$ & $12 / 20$ & - & $1 / 17$ & $1 / 17$ & $10 / 25$ & $12 / 28$ & $18 / 24$ & $/ 28$ & $6 / 26$ & $19 / 20$ & $135 / 371$ \\
\hline 1990 & $0 / 16$ & $2 / 24$ & $15 / 28$ & $0 / 27$ & $3 / 20$ & $5 / 26$ & $1 / 16$ & $4 / 23$ & $17 / 24$ & $3 / 21$ & - & $6 / 16$ & $3 / 17$ & $16 / 25$ & $3 / 28$ & $8 / 23$ & $5 / 28$ & $17 / 25$ & $19 / 20$ & $127 / 408$ \\
\hline 1991 & $1 / 16$ & $2 / 24$ & $18 / 28$ & $1 / 27$ & $3 / 20$ & $1 / 26$ & $5 / 16$ & $4 / 23$ & $17 / 25$ & $8 / 21$ & - & $3 / 16$ & $7 / 17$ & $9 / 25$ & $0 / 28$ & $6 / 23$ & - & $5 / 25$ & $18 / 20$ & $108 / 380$ \\
\hline 1992 & $1 / 16$ & $1 / 23$ & $5 / 26$ & $7 / 24$ & $3 / 20$ & $4 / 26$ & $11 / 16$ & $2 / 23$ & $22 / 25$ & $4 / 21$ & - & $1 / 17$ & $0 / 17$ & $7 / 25$ & $9 / 28$ & $3 / 23$ & $3 / 13$ & $1 / 25$ & $14 / 20$ & $98 / 388$ \\
\hline 1993 & $8 / 16$ & $4 / 22$ & $11 / 26$ & $15 / 24$ & $4 / 20$ & $7 / 26$ & $7 / 16$ & $12 / 24$ & $16 / 25$ & $2 / 21$ & - & $3 / 17$ & $4 / 14$ & $17 / 25$ & $4 / 28$ & $8 / 23$ & $14 / 14$ & $12 / 25$ & $17 / 20$ & $165 / 386$ \\
\hline 1994 & $2 / 16$ & $2 / 22$ & $5 / 20$ & $14 / 26$ & - & $15 / 26$ & $1 / 16$ & $12 / 15$ & $6 / 25$ & $15 / 21$ & - & $3 / 17$ & $4 / 8$ & $17 / 25$ & $0 / 28$ & $15 / 23$ & $5 / 14$ & $19 / 22$ & $12 / 20$ & $147 / 344$ \\
\hline 1995 & $1 / 16$ & $21 / 22$ & $13 / 20$ & $0 / 26$ & - & $9 / 26$ & $0 / 16$ & $1 / 10$ & $9 / 25$ & $12 / 20$ & - & $5 / 17$ & $0 / 10$ & $17 / 25$ & $2 / 28$ & $10 / 23$ & $2 / 14$ & $4 / 21$ & $13 / 20$ & $119 / 339$ \\
\hline 1996 & $0 / 14$ & $8 / 27$ & $3 / 20$ & $12 / 25$ & - & $13 / 26$ & - & $0 / 12$ & $11 / 25$ & $9 / 23$ & - & $11 / 19$ & $3 / 20$ & $6 / 25$ & $0 / 28$ & $0 / 23$ & $/ 14$ & $3 / 26$ & $7 / 20$ & $86 / 347$ \\
\hline 1997 & $1 / 14$ & $9 / 28$ & $13 / 20$ & $23 / 31$ & $1 / 16$ & $8 / 29$ & - & $0 / 27$ & $4 / 25$ & $6 / 23$ & - & $8 / 14$ & $5 / 23$ & $4 / 25$ & $0 / 28$ & $0 / 23$ & $/ 15$ & $10 / 27$ & $5 / 18$ & $97 / 386$ \\
\hline 1998 & $1 / 14$ & $1 / 28$ & $9 / 20$ & $2 / 31$ & $2 / 16$ & $7 / 29$ & - & $0 / 25$ & $13 / 24$ & $4 / 23$ & - & $4 / 17$ & $5 / 23$ & $4 / 25$ & $0 / 28$ & $17 / 29$ & $1 / 14$ & $11 / 28$ & $2 / 18$ & $83 / 392$ \\
\hline 1999 & $0 / 14$ & - & $15 / 20$ & - & $4 / 16$ & $12 / 30$ & - & - & - & - & - & $2 / 17$ & $21 / 22$ & $6 / 25$ & $0 / 22$ & - & $1 / 14$ & - & $3 / 18$ & $64 / 198$ \\
\hline tal & $/ 408$ & $9 / 57$ & $9 / 665$ & $0 / 66$ & $/ 462$ & $/ 270$ & & 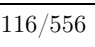 & & & & & & & & & & & & \\
\hline
\end{tabular}


ployment. Data from 1983 is from the OECD's Corporate Data Environment, Table Employment by permanency of the (main) job. Data for Finland in 1995 and 1996 and for Norway are from Eurostat. Data for Sweden are provided by the Statistics Sweden (SCB). Lacking information prior to 1983, we have chosen not to extrapolate the data.

\section{Combined Regions and Periods}

Table D1: The FWCP estimated at 0, -2, -5, and $-\pi$ percent real wage growth. p-values in parentheses.

\begin{tabular}{|c|c|c|c|c|c|c|c|c|c|c|}
\hline \multirow[b]{3}{*}{ Region } & \multirow[b]{3}{*}{ Period } & \multirow[b]{3}{*}{$S$} & \multicolumn{8}{|c|}{ DRWR evaluated below } \\
\hline & & & \multicolumn{2}{|c|}{0 percent } & \multicolumn{2}{|c|}{-2 percent } & \multicolumn{2}{|c|}{-5 percent } & \multicolumn{2}{|c|}{$-\pi$ percent } \\
\hline & & & $Y$ & FWCP & $Y$ & FWCP & $Y$ & FWCP & $Y$ & FWCP \\
\hline Anglo & $1970-79$ & 698 & 245 & $\begin{array}{l}0.048 \\
(0.087)\end{array}$ & 143 & $\begin{array}{l}0.103 \\
(0.015)\end{array}$ & 38 & $\begin{array}{l}0.248 \\
(0.010)\end{array}$ & 0 & $\begin{array}{l}1.000 \\
(0.190)\end{array}$ \\
\hline Anglo & $1980-89$ & 1149 & 564 & $\begin{array}{l}0.029 \\
(0.118)\end{array}$ & 269 & $\begin{array}{l}0.110 \\
(0.003)\end{array}$ & 103 & $\begin{array}{l}0.155 \\
(0.020)\end{array}$ & 26 & $\begin{array}{l}0.453 \\
(0.001)\end{array}$ \\
\hline Anglo & 1990-94 & 595 & 286 & $\begin{array}{l}0.019 \\
(0.322)\end{array}$ & 89 & $\begin{array}{l}0.168 \\
(0.022)\end{array}$ & 25 & $\begin{array}{l}0.146 \\
(0.235)\end{array}$ & 59 & $\begin{array}{l}0.186 \\
(0.039)\end{array}$ \\
\hline Anglo & 1995-99 & 519 & 179 & $\begin{array}{l}0.003 \\
(0.500)\end{array}$ & 67 & $\begin{array}{l}0.062 \\
(0.303)\end{array}$ & 22 & $\begin{array}{l}0.137 \\
(0.271)\end{array}$ & 68 & $\begin{array}{l}0.020 \\
(0.452)\end{array}$ \\
\hline Core & 1970-79 & 794 & 86 & $\begin{array}{l}0.177 \\
(0.014)\end{array}$ & 23 & $\begin{array}{l}0.406 \\
(0.003)\end{array}$ & 5 & $\begin{array}{l}0.585 \\
(0.019)\end{array}$ & 4 & $\begin{array}{l}0.515 \\
(0.083)\end{array}$ \\
\hline Core & $1980-89$ & 1183 & 430 & $\begin{array}{l}0.033 \\
(0.128)\end{array}$ & 136 & $\begin{array}{l}0.163 \\
(0.003)\end{array}$ & 18 & $\begin{array}{l}0.434 \\
(0.004)\end{array}$ & 40 & $\begin{array}{l}0.305 \\
(0.005)\end{array}$ \\
\hline Core & $1990-94$ & 587 & 128 & $\begin{array}{l}0.073 \\
(0.145)\end{array}$ & 29 & $\begin{array}{l}0.204 \\
(0.104)\end{array}$ & 5 & $\begin{array}{l}0.402 \\
(0.144)\end{array}$ & 18 & $\begin{array}{l}0.244 \\
(0.108)\end{array}$ \\
\hline Core & 1995-99 & 546 & 144 & $\begin{array}{l}0.063 \\
(0.132)\end{array}$ & 60 & $\begin{array}{l}0.114 \\
(0.108)\end{array}$ & 20 & $\begin{array}{l}0.062 \\
(0.416)\end{array}$ & 63 & $\begin{array}{l}0.144 \\
(0.061)\end{array}$ \\
\hline Nordic & $1970-79$ & 474 & 86 & $\begin{array}{l}0.026 \\
(0.400)\end{array}$ & 27 & $\begin{array}{l}0.228 \\
(0.059)\end{array}$ & 3 & $\begin{array}{l}0.724 \\
(0.003)\end{array}$ & 1 & $\begin{array}{l}0.374 \\
(0.524)\end{array}$ \\
\hline Nordic & $1980-89$ & 888 & 335 & $\begin{array}{l}0.017 \\
(0.296)\end{array}$ & 182 & $\begin{array}{l}0.068 \\
(0.049)\end{array}$ & 39 & $\begin{array}{l}0.189 \\
(0.050)\end{array}$ & 3 & $\begin{array}{l}0.665 \\
(0.019)\end{array}$ \\
\hline Nordic & 1990-94 & 354 & 81 & $\begin{array}{l}0.037 \\
(0.358)\end{array}$ & 23 & $\begin{array}{l}0.204 \\
(0.089)\end{array}$ & 3 & $\begin{array}{l}0.301 \\
(0.369)\end{array}$ & 12 & $\begin{array}{l}0.294 \\
(0.105)\end{array}$ \\
\hline Nordic & 1995-99 & 260 & 13 & $\begin{array}{l}0.310 \\
(0.088)\end{array}$ & 3 & $\begin{array}{l}0.573 \\
(0.074)\end{array}$ & 0 & $\begin{array}{l}1.000 \\
(0.132)\end{array}$ & 2 & $\begin{array}{l}0.759 \\
(0.009)\end{array}$ \\
\hline South & $1970-79$ & 258 & 36 & $\begin{array}{l}-0.020 \\
(0.601)\end{array}$ & 21 & $\begin{array}{l}0.058 \\
(0.442)\end{array}$ & 13 & $\begin{array}{c}-0.088 \\
(0.695)\end{array}$ & 0 & $\begin{array}{l}1.000 \\
(0.244)\end{array}$ \\
\hline South & 1980-89 & 497 & 216 & $\begin{array}{l}0.034 \\
(0.195)\end{array}$ & 168 & $\begin{array}{l}0.038 \\
(0.216)\end{array}$ & 110 & $\begin{array}{l}0.072 \\
(0.129)\end{array}$ & 5 & $\begin{array}{l}0.446 \\
(0.105)\end{array}$ \\
\hline South & 1990-94 & 370 & 150 & $\begin{array}{l}-0.040 \\
(0.787)\end{array}$ & 88 & $\begin{array}{c}-0.039 \\
(0.709)\end{array}$ & 30 & $\begin{array}{l}0.174 \\
(0.134)\end{array}$ & 4 & $\begin{array}{l}0.482 \\
(0.115)\end{array}$ \\
\hline South & 1995-99 & 337 & 113 & $\begin{array}{l}0.093 \\
(0.089)\end{array}$ & 44 & $\begin{array}{l}0.180 \\
(0.075)\end{array}$ & 15 & $\begin{array}{l}0.161 \\
(0.289)\end{array}$ & 19 & $\begin{array}{l}0.353 \\
(0.022)\end{array}$ \\
\hline
\end{tabular}

Note: See Table 1 


\section{E Robustness}

To further explore the robustness of our results, we perform an extensive sensitivity analysis of our main approach by varying the key assumptions. More specifically, we try different assumptions along three dimensions of the underlying notional distribution, namely the shape, the location, and the dispersion. As to the shape of the underlying distribution, in addition to the common distribution, we also try distributions that are country-specific and period-specific. In particular, we construct the underlying notional distribution separately for each country (period), based on all observations from this country (period), and then proceed with the method as before. For the location of the distribution, we follow Knoppik and Beissinger (2003) by also trying the 80th percentile, the motivation is that in some country-years, the median wage change is potentially affected by DRWR, while this is rarely the case for the 80th percentile. For the dispersion of the distribution, we consider two alternatives to the inter-percentile range. As the 35th percentile potentially is quite often affected by DRWR, we also consider an alternative that does not rely on any specific percentile, the mean deviation from the mean (MDEV). However, if DRWR is at work, it will compress the left part of the distribution and thus reduce both these dispersion measures, inducing a downward bias in our measure of downward rigidity. To avoid this, we also measure dispersion by the predicted inter-percentile range, found in country-specific regressions of the actual inter percentile ranges on the lagged inter percentile range; inflation; the average inter percentile range in other countries in the same region; a trend; and a squared trend. Note that several of these alternative measures are likely to involve considerably more random noise than the main measures (MDEV and the 80th percentile are sensitive to outliers, while the predicted IPR is sensitive to prediction error). Thus, we would expect considerable variation in the estimated FWCP. However, trying such diverse sets of measures provides information about the robustness of the broad picture. Taken together, to construct the notional distributions we use 18 different combinations of three distributional shapes (common, country-specific, or period-specific) $\times$ two measures of location (median or 80 th percentile) $\times$ three dispersions (IPR, MDEV, or predicted IPR).

Figure E1 presents measures of the 18 estimates of the FWCP for each of the limits $0,-1$, $-2,-5$ and $-\pi$ percent (that is nominal zero). The estimates from Table 1 are indicated with a dot, a cross indicates an estimate that is significant at the 5 percent level, while the plus signs indicate FWCP estimates that are not significant. The number above the estimates is the number of significant estimates. We observe that while there is considerable variation in the estimates, the main features from the Table 1 still hold. There is clear evidence of DRWR at -2 and -5 percent growth rates in the overall sample, where 17 and 14 of the 18 FWCP estimates are significant. There is some evidence of DRWR at zero or -1 percent, but these point estimates are closer to 


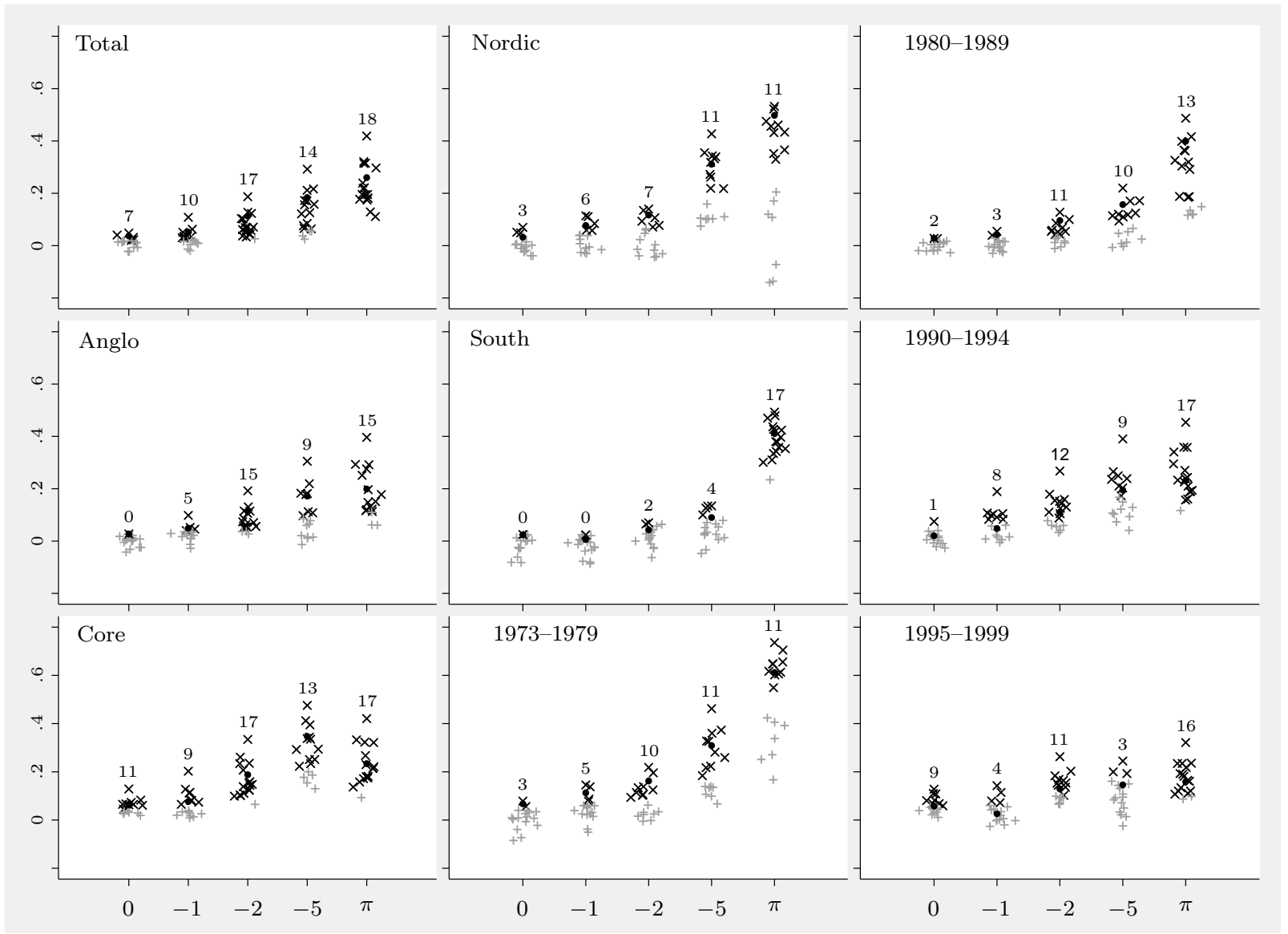

Figure E1: Estimates of the fraction of real wage cuts prevented evaluated at 0, -1, -2 and -5 percent, and the fraction of nominal wage cuts prevented. There are 18 estimates per evaluation criteria. A cross indicates a significant estimate at 5 percent while a plus sign indicates an insignificant estimate. The number of significant estimates reports are reported on top of each column.

zero, and few are significantly larger than zero. The evidence for DNWR is stronger than the evidence for DRWR, with higher FWCP estimates, where 18 are significant. In the other panels of Figure E1, we display similar charts for time periods and regions. There is considerable variation, yet the broad picture is not affected. Overall, there is clear evidence of DRWR, although the extent is moderate. Significance levels and FWCPs are higher at -2 and -5 percent than at zero, and also weaker and smaller in the South than in the other regions. 


\section{F Symmetric Notional Distributions}

Table F1: The FWCP estimated at 0, -2, -5 , and $-\pi$ percent real wage growth. Symmetric and country-year specific notional distributions. p-values in parentheses.

\begin{tabular}{|c|c|c|c|c|c|c|c|c|c|}
\hline \multirow[b]{3}{*}{ Category } & \multirow[b]{3}{*}{$S$} & \multicolumn{8}{|c|}{ DRWR evaluated below } \\
\hline & & \multicolumn{2}{|c|}{0 percent } & \multicolumn{2}{|c|}{-2 percent } & \multicolumn{2}{|c|}{-5 percent } & \multicolumn{2}{|c|}{$-\pi$ percent } \\
\hline & & $Y$ & FWCP & $Y$ & FWCP & $Y$ & FWCP & $Y$ & FWCP \\
\hline All & 9505 & 3092 & $\begin{array}{l}0.023 \\
(0.020)\end{array}$ & 1372 & $\begin{array}{l}0.070 \\
(0.000)\end{array}$ & 449 & $\begin{array}{l}0.127 \\
(0.000)\end{array}$ & 324 & $\begin{array}{c}0.200 \\
(0.000)\end{array}$ \\
\hline \multicolumn{10}{|l|}{ Periods } \\
\hline 1970-79 & 2224 & 453 & $\begin{array}{l}0.036 \\
(0.128)\end{array}$ & 214 & $\begin{array}{l}0.041 \\
(0.207)\end{array}$ & 59 & $\begin{array}{l}0.170 \\
(0.040)\end{array}$ & 5 & $\begin{array}{c}0.501 \\
(0.061)\end{array}$ \\
\hline $1980-89$ & 3717 & 1545 & $\begin{array}{l}0.018 \\
(0.111)\end{array}$ & 755 & $\begin{array}{l}0.035 \\
(0.073)\end{array}$ & 270 & $\begin{array}{l}0.100 \\
(0.010)\end{array}$ & 74 & $\begin{array}{l}0.230 \\
(0.009)\end{array}$ \\
\hline $1990-94$ & 1906 & 645 & $\begin{array}{c}0.008 \\
(0.398)\end{array}$ & 229 & $\begin{array}{l}0.120 \\
(0.007)\end{array}$ & 63 & $\begin{array}{l}0.102 \\
(0.194)\end{array}$ & 93 & $\begin{array}{c}0.213 \\
(0.005)\end{array}$ \\
\hline $1995-99$ & 1662 & 449 & $\begin{array}{l}0.047 \\
(0.078)\end{array}$ & 174 & $\begin{array}{l}0.167 \\
(0.001)\end{array}$ & 57 & $\begin{array}{l}0.219 \\
(0.017)\end{array}$ & 152 & $\begin{array}{c}0.159 \\
(0.005)\end{array}$ \\
\hline \multicolumn{10}{|l|}{ Regions } \\
\hline Anglo & 2961 & 1274 & $\begin{array}{l}0.003 \\
(0.428)\end{array}$ & 568 & $\begin{array}{l}0.067 \\
(0.007)\end{array}$ & 188 & $\begin{array}{l}0.134 \\
(0.008)\end{array}$ & 153 & $\begin{array}{l}0.124 \\
(0.029)\end{array}$ \\
\hline Core & 3110 & 788 & $\begin{array}{c}0.073 \\
(0.001)\end{array}$ & 248 & $\begin{array}{l}0.152 \\
(0.000)\end{array}$ & 48 & $\begin{array}{c}0.334 \\
(0.000)\end{array}$ & 125 & $\begin{array}{c}0.220 \\
(0.000)\end{array}$ \\
\hline Nordic & 1976 & 515 & $\begin{array}{c}-0.012 \\
(0.693)\end{array}$ & 235 & $\begin{array}{l}0.018 \\
(0.349)\end{array}$ & 45 & $\begin{array}{l}0.118 \\
(0.151)\end{array}$ & 18 & $\begin{array}{l}0.359 \\
(0.018)\end{array}$ \\
\hline South & 1462 & 515 & $\begin{array}{l}0.023 \\
(0.224)\end{array}$ & 321 & $\begin{array}{l}0.040 \\
(0.162)\end{array}$ & 168 & $\begin{array}{l}0.036 \\
(0.279)\end{array}$ & 28 & $\begin{array}{c}0.333 \\
(0.007)\end{array}$ \\
\hline
\end{tabular}

Note: See Table 1 